Article

\title{
Forest Ecosystem Services: Issues and Challenges for Biodiversity, Conservation, and Management in Italy
}

\author{
Matteo Vizzarri ${ }^{1, \dagger, *}$, Roberto Tognetti ${ }^{1,2, \dagger}$ and Marco Marchetti ${ }^{1, \dagger}$
}

1 Dipartimento di Bioscienze e Territorio (DiBT), Contrada Fonte Lappone, Pesche, Isernia 86090, Italy; E-Mails: tognetti@unimol.it (R.T.); marchettimarco@unimol.it (M.M.)

2 The EFI Project Centre on Mountain Forests (MOUNTFOR), Edmund Mach Foundation, Via E. Mach 1, San Michele all'Adige, Trento 38010, Italy

$\dagger$ These authors contributed equally to this work.

* Author to whom correspondence should be addressed; E-Mail: matteo.vizzarri@unimol.it; Tel.: +39-0874-404171; Fax: +39-0874-1864909.

Academic Editors: Jean-Claude Ruel and Eric J. Jokela

Received: 30 January 2015 / Accepted: 20 May 2015 / Published: 28 May 2015

\begin{abstract}
Although forest ecosystems are fundamental sources of services and global biodiversity, their capacity to maintain these benefits in the future is potentially threatened by anthropogenic impacts such as climate change, land use, and unsustainable management practices. Thus far, studies focusing on forests and their services have gained less attention compared with studies on other biomes. Additionally, management practices may potentially undermine the capacity of forests to sustain biodiversity conservation and services in the future, especially outside protected areas. This study linked the concepts of biodiversity and forest ecosystem services at the national level in Italy. Through a downscaled review, we first analyzed management issues, challenges, and needs within the context of forest ecosystem services. We then carried out a survey on protected areas. The results show that forest biodiversity supports the provision of other services and, hence, needs to be preserved and supported by adaptive management practices. Current research on forest ecosystem services must extend policy trajectories to protected areas (i.e., National Parks) as centers of biodiversity and models of the sustainable use of resources.
\end{abstract}


Keywords: forest ecosystem services; biodiversity conservation; forest management; protected areas

\section{Introduction}

Ecosystem services (ESs) are considered those tangible and intangible benefits that ecosystems provide to society. The concept of ESs was originally developed to raise awareness of biodiversity conservation [1]. Although forests are recognized as fundamental sources of ESs, they are continuously threatened or degraded by human-induced effects [2], such as global climate change [3], land use and cover change [4], and unsustainable management practices [5]. Indeed, the total loss of forest cover was approximately five million ha $y^{-1} \mathrm{r}^{-1}$ between 2000 and 2010 [6]. In Italy, it has been reported that approximately $7000 \mathrm{ha} \cdot \mathrm{year}^{-1}$ of forests have been converted to other land uses [7].

A large number of studies concerning forest ecosystem services (FESs) have focused on policy measures and issues related to the decision-making process. Such studies examine ways to improve the availability of FESs at different scales, ranging from specific landscapes to the global perspective (e.g., [8]), and to preserve biodiversity and habitats (e.g., [9]). Forest management entails long-term decisions and addresses uncertain trends of future conditions and, thus, is often ancillary to other impending issues (e.g., [10,11]). Studies focusing on specific forest ecosystem processes (e.g., $[12,13])$ and on the effects of land use change on FES provision [14,15]) are still rare. In Italy, FESs have been mainly linked to the concepts of multi-functionality (i.e., the capacity of forests to provide several services simultaneously), naturalness, and biodiversity conservation [16]. Related research contributions have been scarce and in many cases refer to the assessment of the whole set of FESs (e.g., [17-20]) or to their economic evaluation (e.g., [21-24]). Despite the increasing importance of certain FESs (e.g., carbon sequestration, availability of mushrooms and truffles, opportunity for tourism and recreation, conservation of biodiversity and habitat integrity) for local communities in Italy, the main difficulty in forest management remains the assessment of the economic income from services rather than timber. In this sense, the successful implementation of regulatory instruments for FESs in Italy concerns payments for environmental services (e.g., [25]). On the other hand, public awareness about the importance of FESs is often neglected, especially within the context of decision-making processes regarding forest management at the local scale ([26]).

Within the ES framework, biodiversity is closely linked to the ecosystems' functionality and to human wellbeing in the following ways: (i) biodiversity has a multilayered relationship with other ESs-As a regulator of ecosystem processes, as a service in itself, and as a good [26]; (ii) the loss of biodiversity is one of the most influential drivers of ecosystem change in terms of primary production and decomposition [27]; and (iii) the loss of biodiversity-dependent ESs is likely to accentuate inequality and marginalization of the most vulnerable sectors of society [28]. These key points have been widely reviewed [29] and used as a basis to support research proposals aimed at biodiversity conservation worldwide (e.g., "The IUCN Red List of Ecosystems"; [30]). Moreover, several regulatory frameworks concerning the safeguarding of biodiversity and ESs are available at the global (e.g., CBD "2020 Aichi 
Target", www.cbd.int/sp/targets), European (e.g., "EU Biodiversity Strategy"; [31]), and Italian (e.g., Strategia Nazionale per la Biodiversità [Italian National Biodiversity Strategy]; [32]) levels.

Considering that the management of ecosystems (forests included) depends on the scale at which it is implemented [33], the Protected Areas Network (PAN) plays a key role in addressing global biodiversity conservation (see, e.g., [34]) as well as the provision of other services [35]. For example, PAN covers more than $12 \%$ of the Earth's land area, where more than 7.5 million ha belong to forest biomes [36]. In Italy, forests and other wooded lands that are included in PAN at the country level cover more than 1.5 million ha (approximately $50 \%$ of the total PAN). Italian forest stands are often degraded or oversimplified due to past management practices and other disturbances (e.g., drought, fires, abandonment of rural practices) [37]. Under these conditions, the conservation of biodiversity and the provision of services are widely compromised. Therefore, many forest areas are currently unmanaged or under protection, in contrast to areas that have been overexploited (e.g., [38]). Moreover, the abandonment of mountain areas and the urban sprawl have caused both the expansion and reduction of forests, respectively, and, subsequently, a rearrangement of sources for related services (e.g., [39]). However, old-growth forests within PAN are considered biodiversity hotspots in Italy and need to be valorized through close-to-nature forest management (e.g., [40]).

Forest management will face significant challenges if the capacity of forests to provide FESs is to be maintained in the future under global change scenarios [41]. Accordingly, conventional forest management approaches (i.e., those mainly oriented toward maximizing economic income) need to be revised in order to implement the concepts of sustainability and resilience. Indeed, in contrast to the widely held view that forest management should provide services for human uses (e.g., thinning for timber production), maintaining forest functionality within the context of a changing environment may require focusing on the forests themselves and on strategies to reduce their vulnerability to increasing stress conditions (e.g., thinning for water yield).

Forest conditions that best meet the demands for ESs must first be defined. Then, the management pathways that allow forests to be adapted to this target need to be identified. However, targeting forest sustainability is not an easy task, as it depends on legacies from past management as well as uncertainties in the future climate. For example, adaptive management [42,43], the ecosystem approach [44], and "resilience thinking" $[45,46]$ should be considered as the most suitable forestry approaches addressing sustainability challenges [47]. In the same way, the systemic silviculture in Italy promotes the management of forests as complex adaptive systems for sustainability and resilience (e.g., [48]).

The general aim of this study is to link biodiversity and ESs at the national level by analyzing both management and research issues in wider contexts in terms of challenges and needs. The two main objectives of the study are as follows: (1) to examine the state of knowledge about FESs by downscaling the most representative literature from the global to the Italian scale and by analyzing the aims and content of national studies by comparing them with studies available at a broader scale; and (2) to analyze the implementation of FESs in forest management practices on a selection of Protected Areas in Italy as a model system to describe the current conditions and the desirable targets for close-to-nature forest management. 


\section{Methods}

\subsection{Analysis of Management and Research Contexts}

The literature review is based on a "by-keywords" search using both the SCOPUS (www.scopus.com) and ISI-Web of Science (apps.webofknowledge.com) databases. The review on EU-funded research projects is based on a "free text" search using the Community Research and Development Information Service (CORDIS) of the European Commission (www.cordis.europa.eu). For the reviews, the reference time period was defined as 2000 to 2012 . The main evaluation parameters are (i) the number of publications per year and (ii) the analysis of the main contents per publication. The review is structured according to the following review sections: (i) Review Section 1 ("ecosystem services at the global scale") provides an overview of the scientific contributions concerning ecosystem or environmental services and their linkages with forests, mainly at the global level; (ii) Review Section 2 ("ecosystem service categories at the global scale") analyzes the different service categories (generally for all ecosystems); (iii) Review Section 3 ("forest ecosystem service categories at the global scale") analyzes the different service categories (specifically for forests); (iv) Review Section 4 ("ecosystem services in Italy") concerns publications about ESs (and forests) at national level, i.e., Italy; and (v) Review Section 5 ("projects within the context of ecosystem services") looks at the number of available projects (concluded or currently underway) strictly linked to the FES topic. The number of publications is assessed per each review section independently. In other words, a publication found in Review Section 1 can be found in Review Section 2 as well. Table 1 reports the main methodological characteristics of the literature review.

Table 1. Details on the procedure adopted for the literature review.

\begin{tabular}{|c|c|c|c|c|}
\hline $\begin{array}{c}\text { Review } \\
\text { Section (RS) } \\
\end{array}$ & $\begin{array}{c}\text { Review Section } \\
\text { Title } \\
\end{array}$ & Search Engine & Search Strength & $\begin{array}{c}\text { Evaluation Parameters } \\
\text { (Expected Results) }\end{array}$ \\
\hline \multirow{6}{*}{1} & \multirow{6}{*}{$\begin{array}{l}\text { Ecosystem services } \\
\text { at global scale }\end{array}$} & \multirow{15}{*}{$\begin{array}{l}\text { Scopus, ISI-Web } \\
\text { of Science }\end{array}$} & “ecosystem services” OR & \multirow{15}{*}{$\begin{array}{l}\text { number of publications } \\
\left.\text { per year ( } n \text { pub year }^{-1}\right)\end{array}$} \\
\hline & & & "environmental services" & \\
\hline & & & “ecosystem services” OR “environmental & \\
\hline & & & services" AND "forests" & \\
\hline & & & "forest ecosystem services" OR & \\
\hline & & & "forest environmental services" & \\
\hline \multirow{9}{*}{2} & \multirow{9}{*}{$\begin{array}{l}\text { Ecosystem services } \\
\text { categories at global } \\
\text { scale }\end{array}$} & & "provisioning services" & \\
\hline & & & AND “ecosystems” & \\
\hline & & & "regulating services" AND "ecosystems" & \\
\hline & & & $\begin{array}{l}\text { "biodiversity services" OR "habitat } \\
\text { services" OR "supporting services" }\end{array}$ & \\
\hline & & & AND “ecosystems" & \\
\hline & & & "cultural services" OR “aesthetic services" & \\
\hline & & & OR “amenity services" OR "tourism & \\
\hline & & & services" OR "recreational services" & \\
\hline & & & AND “ecosystems" & \\
\hline
\end{tabular}


Table 1. Cont.

\begin{tabular}{|c|c|c|c|c|}
\hline $\begin{array}{c}\text { Review } \\
\text { Section (RS) }\end{array}$ & $\begin{array}{c}\text { Review Section } \\
\text { Title }\end{array}$ & Search Engine & Search Strength & $\begin{array}{c}\text { Evaluation Parameters } \\
\text { (Expected Results) }\end{array}$ \\
\hline \multirow{11}{*}{3} & \multirow{11}{*}{$\begin{array}{l}\text { Forest ecosystem } \\
\text { services categories } \\
\text { at global scale }\end{array}$} & & "provisioning services" AND “forests" & \\
\hline & & & OR "forest ecosystems" & \\
\hline & & & "regulating services" AND "forests" & \\
\hline & & & OR "forest ecosystems" & \\
\hline & & & "biodiversity services" OR "habitat & \\
\hline & & & services" OR "supporting services" AND & \\
\hline & & & “forests" OR “forest ecosystems" & \\
\hline & & & "cultural services" OR "aesthetic services" & \\
\hline & & & OR “amenity services” OR “tourism & \\
\hline & & & services" OR "recreational services" AND & \\
\hline & & & “forests" OR “forest ecosystems" & \\
\hline \multirow{5}{*}{4} & \multirow{5}{*}{$\begin{array}{c}\text { Ecosystem services } \\
\text { in Italy }\end{array}$} & & "ecosystem services" AND "Italy" & \multirow{5}{*}{$\begin{array}{c}\text { number of publications } \\
\text { per year ( } n \text { pub year }^{-1} \text { ); } \\
\text { analysis of the main } \\
\text { contents (number of } \\
\text { publications } \mathrm{TA}^{-1} \text { ) }\end{array}$} \\
\hline & & & "forest ecosystem services" AND "Italy" & \\
\hline & & & "ecosystem services" AND "forests" & \\
\hline & & & AND "Italy" & \\
\hline & & & "forest ecosystem services" (AND "Italy”) & \\
\hline 5 & $\begin{array}{l}\text { Projects in the } \\
\text { context of } \\
\text { ecosystem services }\end{array}$ & CORDIS & & $\begin{array}{l}\text { Number of projects; } \\
\text { main contents and } \\
\text { objectives }\end{array}$ \\
\hline
\end{tabular}

The publications found in Review Section 4 were then grouped into specific thematic areas (TAs) by verifying the consistency of their contents with the theoretical concepts and aims behind each TA. We selected the following TAs: (i) ES assessment (approaches, techniques, and methods); (ii) the role of ESs within the policy context; (iii) ESs in urban (and semi-natural) areas; (iv) ESs and local communities; (v) the economics of ESs; and (vi) ESs and land use, cover, and change (LUCC). These TAs were chosen for their significance in ES-related research. Following this approach, each publication has been analyzed for a specific TA.

\subsection{The Survey of Protected Areas in Italy}

A 20-page questionnaire on the role of FESs in socio-economic and planning contexts was prepared and then submitted to the authorities of a target group of National and Regional Parks (NRPs) in Italy. Fifteen NRPs were selected according to the following criteria: (i) regional representativeness (more than $80 \%$ of the NRPs should be represented) and (ii) forest area inclusiveness (more than $25 \%$ of the total forest area should be included). The questionnaires contained different "closed-questions" and were divided into the following seven sections: (i) general information; (ii) the main FESs provided; (iii) the local stakeholder-FES relationship; (iv) currently available governance instruments; (v) the main factors influencing decision-making processes; (vi) linkages between decision-making processes and research activities; and (vii) FES relevance in forest management. The interviewees (managers of the NRPs) were asked to answer the questionnaire by using ranking scales or true/false options. Then, the answers were separately analyzed for each section. Table 2 reports details about the calculation used to analyze the 
questionnaire results. For further details about the structure of the questionnaires, the reader is referred to Supplementary 1.

Table 2. Calculation made for each questionnaire section.

\begin{tabular}{|c|c|}
\hline Section & Calculation \\
\hline $\begin{array}{l}\text { Section } 1-\text { General description } \\
\text { of the area }\end{array}$ & No calculation \\
\hline $\begin{array}{l}\text { Section } 2 \text { - Forest Ecosystem } \\
\text { Services relevance }\end{array}$ & $\begin{array}{l}\text { A unique relevance value }(R E L) \text { of each ecosystem service Division and for all of } \\
\text { respondents was calculated by using the following equation: } \\
R E L=\frac{\sum_{i=1}^{m}\left[\sum_{j=1}^{n}\left(R E L_{j}\right)\right]_{i}}{m}[0 \div 4] \\
\text { Where: } R E L \text { is the relevance value for the ecosystem services Division (e.g., nutrition, } \\
\text { materials, energy, etc.); } R E L_{j} \text { is the relevance value for the } j \text {-th ecosystem service } \\
\text { Group; } n \text { is the total number of ecosystem services Groups; and } m \text { is the total number } \\
\text { of respondents. }\end{array}$ \\
\hline $\begin{array}{l}\text { Section } 3 \text { - Relationship } \\
\text { between local stakeholders and } \\
\text { Forest Ecosystem Services }\end{array}$ & $\begin{array}{l}\text { A unique influence value }(I N F) \text { was calculated for each Stakeholder typology and ES } \\
\text { Division between all respondents by using the following equation: } \\
I N F=\frac{\sum_{i=1}^{m}\left(I N F_{i}\right)}{m}[-1 \div 1] \\
\text { Where: } I N F_{i} \text { is the influence value on the } i \text {-th ecosystem services Division; and } m \text { is } \\
\text { the total number of respondents. }\end{array}$ \\
\hline $\begin{array}{l}\text { Section } 4 \text { - Governance } \\
\text { instruments at work in the area }\end{array}$ & Answers were converted into numeric values, as follows: TRUE in 1, and FALSE in 0. \\
\hline $\begin{array}{l}\text { Section } 5 \text { - Factors considered } \\
\text { in decision-making processes }\end{array}$ & $\begin{array}{l}\text { Answers were converted into numeric values, as follows: TRUE in 1, PARTIALLY } \\
\text { TRUE in } 0.5 \text {, and FALSE in } 0 .\end{array}$ \\
\hline $\begin{array}{l}\text { Section } 6 \text { - Decision-making } \\
\text { processes and research } \\
\text { activities }\end{array}$ & $\begin{array}{l}\text { Answers were converted into numeric values, as follows: TRUE in 1, PARTIALLY } \\
\text { TRUE in } 0.5 \text {, and FALSE in } 0 .\end{array}$ \\
\hline $\begin{array}{l}\text { Section } 7 \text { - Forest Ecosystem } \\
\text { Services relevance in forest } \\
\text { management }\end{array}$ & $\begin{array}{l}\text { The influence value of ecosystem services in Forest Management }(F E S F M) \text { was } \\
\text { calculated for each of the three elements (priority, difficulty, and relevance) and for } \\
\text { each FES Division by using the following equation: } \\
F E S F M=\frac{\sum_{i=1}^{m}\left(F E S F M_{i}\right)}{m}[0 \div 5] \\
\text { Where: } F E S F M_{i} \text { is the influence value of the } i \text {-th FES in forest management; and } m \text { is } \\
\text { the total number of respondents. }\end{array}$ \\
\hline
\end{tabular}

The means resulting from the survey on FES relevance and the priority for management guidelines were normally distributed and compared with a $t$-test for paired samples with a significance of $p<0.05$ (SPSS Inc., Chicago, IL, USA).

\section{Results}

\subsection{Downscaling Exercise}

We found more than 9000 records for both search engines. Table 3 summarizes the main outcomes of our literature review. No result was found for the "forest ecosystem services" AND "Italy" search strength. 
Table 3. Summary of review results in terms of number of records found, and relative differences per search engine (time period: 2000 to 2012).

\begin{tabular}{|c|c|c|c|c|c|}
\hline $\begin{array}{l}\text { Review } \\
\text { Section }\end{array}$ & Review Section Title & Search Strenght & $\begin{array}{l}\text { SCOPUS } \\
\text { (A) }\end{array}$ & $\begin{array}{l}\text { ISI-Web of } \\
\text { Science (B) }\end{array}$ & $\begin{array}{c}\text { Relative } \\
\text { Difference (A-B) }\end{array}$ \\
\hline \multirow{3}{*}{1} & \multirow{3}{*}{$\begin{array}{l}\text { Ecosystem services at } \\
\text { global scale }\end{array}$} & $\begin{array}{l}\text { “ecosystem services” OR } \\
\text { "environmental services” }\end{array}$ & 7313 & 7425 & -112 \\
\hline & & $\begin{array}{l}\text { "ecosystem services" OR } \\
\text { "environmental services" AND } \\
\text { "forests" }\end{array}$ & 1695 & 6504 & -4809 \\
\hline & & $\begin{array}{l}\text { "forest ecosystem services" OR } \\
\text { "forest environmental services" }\end{array}$ & 145 & 179 & -34 \\
\hline \multirow{4}{*}{2} & \multirow{4}{*}{$\begin{array}{l}\text { Ecosystem services } \\
\text { categories at global } \\
\text { scale }\end{array}$} & $\begin{array}{l}\text { "provisioning services" AND } \\
\text { "ecosystems" }\end{array}$ & 70 & 43 & 27 \\
\hline & & $\begin{array}{l}\text { "regulating services" AND } \\
\text { "ecosystems" }\end{array}$ & 62 & 31 & 31 \\
\hline & & $\begin{array}{l}\text { "biodiversity services" OR } \\
\text { "habitat services" OR } \\
\text { "supporting services" AND } \\
\text { "ecosystems" }\end{array}$ & 69 & 55 & 14 \\
\hline & & $\begin{array}{l}\text { "cultural services" OR } \\
\text { "aesthetic services" OR } \\
\text { "amenity services" OR "tourism } \\
\text { services" OR "recreational } \\
\text { services" AND “ecosystems" }\end{array}$ & 108 & 406 & -298 \\
\hline \multirow{4}{*}{3} & \multirow{4}{*}{$\begin{array}{l}\text { Forest ecosystem } \\
\text { services categories at } \\
\text { global scale }\end{array}$} & $\begin{array}{l}\text { "provisioning services" AND } \\
\text { "forests" OR "forest } \\
\text { ecosystems" }\end{array}$ & 17 & 11 & 6 \\
\hline & & $\begin{array}{l}\text { "regulating services" AND } \\
\text { "forests" OR "forest } \\
\text { ecosystems" }\end{array}$ & 14 & 13 & 1 \\
\hline & & $\begin{array}{l}\text { "biodiversity services" OR } \\
\text { "habitat services" OR } \\
\text { "supporting services" AND } \\
\text { "forests" OR "forest } \\
\text { ecosystems" }\end{array}$ & 14 & 25 & -11 \\
\hline & & $\begin{array}{l}\text { "cultural services" OR } \\
\text { "aesthetic services" OR } \\
\text { "amenity services" OR "tourism } \\
\text { services" OR "recreational } \\
\text { services" AND "forests" OR } \\
\text { "forest ecosystems" }\end{array}$ & 42 & 226 & -184 \\
\hline \multirow{3}{*}{4} & \multirow{3}{*}{$\begin{array}{l}\text { Ecosystem services in } \\
\text { Italy }\end{array}$} & $\begin{array}{l}\text { "ecosystem services" AND } \\
\text { "Italy" }\end{array}$ & 20 & 25 & -5 \\
\hline & & $\begin{array}{l}\text { "forest ecosystem services" } \\
\text { AND "Italy" }\end{array}$ & 0 & 0 & 0 \\
\hline & & $\begin{array}{l}\text { "ecosystem services" AND } \\
\text { "forests" AND "Italy" }\end{array}$ & 2 & 8 & -6 \\
\hline 5 & $\begin{array}{l}\text { Projects in the context } \\
\text { of ecosystem services }\end{array}$ & Deatailed & ults in Sup & mentary 2 & \\
\hline
\end{tabular}

We selected 350 papers as the most relevant in understanding the ES research topic according to their relative citations, publishing dates, and keywords. We analyzed the same papers in terms of their content, 
results, conclusions, and relevance within the ES topic. In Review Section 4, we reviewed 34 publications previously grouped into different TAs. Detailed results per review section are reported.

3.1.1. Review Section 1-Ecosystem Services at Global Scale

Figure 1 reports the number of publications from 2000 to 2012 for Review Section 1.
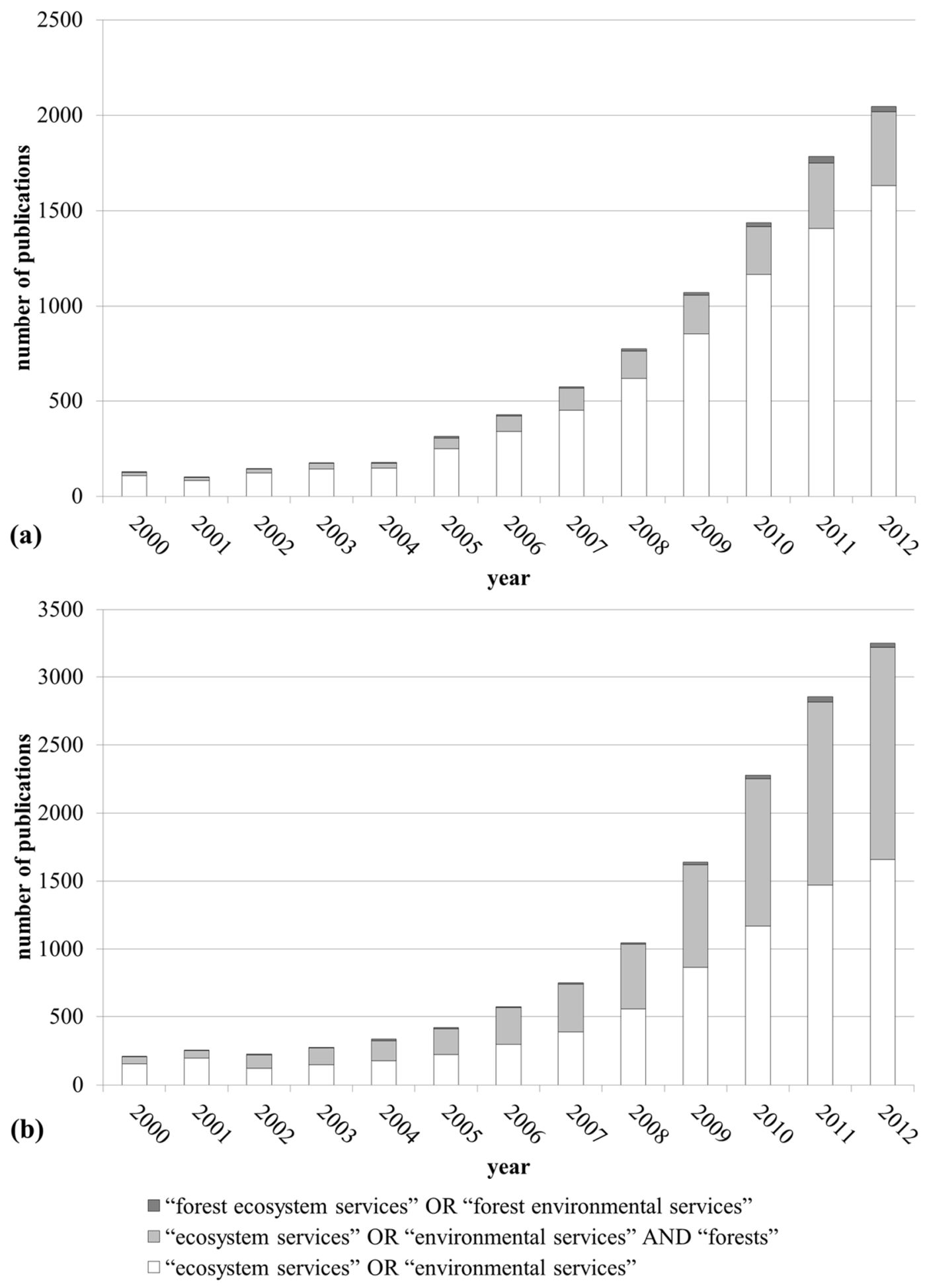

Figure 1. Trends of the number of publications per year for Review Section 1, as found by using SCOPUS (a) or ISI-Web of Science (b). 
Considering the search strength of "ecosystem services" OR "environmental services", the number of publications increased by 1382 (SCOPUS; Figure 1a) and 1434 (ISI-Web of Science; Figure 1b) units after the Millennium Ecosystem Assessment in 2005. In this case, the total number of publications for SCOPUS was $1.6 \%$ less than that for ISI-Web of Science in 2012. Considering the "ecosystem services" OR "environmental services" AND "forests" search strength, the number of publications increased by 331 (SCOPUS; Figure 1a) and 1372 (ISI-Web of Science; Figure 1b) units after the Millennium Ecosystem Assessment in 2005. In this case, the number of publications reported by SCOPUS was three times less than that obtained from ISI-Web of Science. Considering the "forest ecosystem services" OR "forest environmental services" search strength, the number of publications increased by 19 (SCOPUS; Figure 1a) and 26 (ISI-Web of Science; Figure 1b) units after the Millennium Ecosystem Assessment in 2005. In this case, the total number of publications was $25 \%$ less than that for ISI-Web of Science in 2012. These results demonstrate the global interest by the research community on ES-related topics, especially after the Millennium Ecosystem Assessment release in 2005.

\subsubsection{Review Sections 2 and 3-Ecosystem Service Categories at the Global Scale (Including} Forest Ecosystems)

Figure 2 reports the number of publications from 2000 to 2012 for Review Sections 2 and 3.
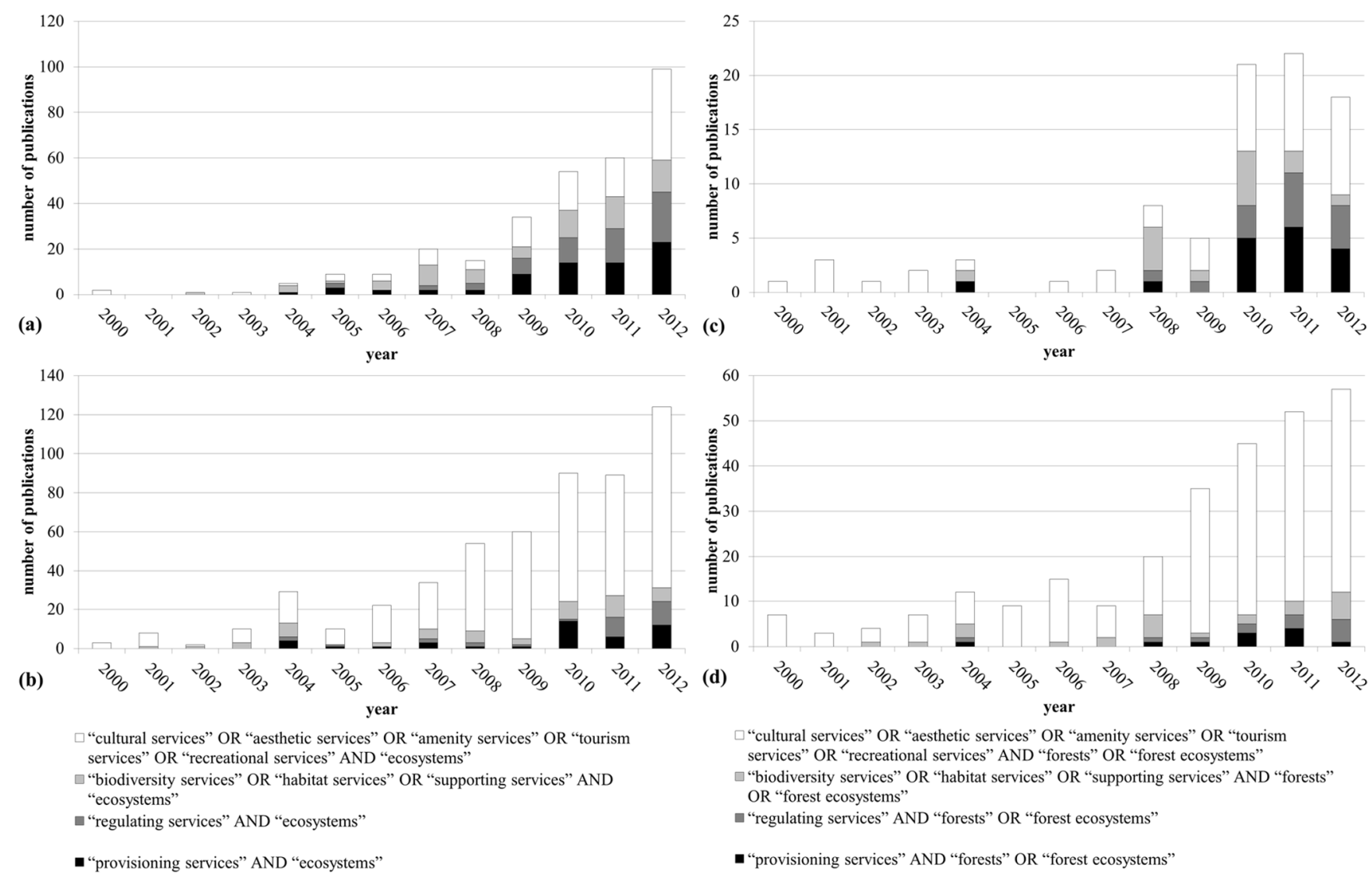

Figure 2. Trends of the number of publications per year for Review Sections $2(\mathbf{a}, \mathbf{b})$ and 3 $(\mathbf{c}, \mathbf{d})$, and for SCOPUS (a,c) and ISI-Web of Science $(\mathbf{b}, \mathbf{d})$. 
Considering the "provisioning services" AND "ecosystems" (PROV-E) and "regulating services" AND "ecosystems" (REG-E) search strengths, the results show that the number of publications rapidly increased after 2008 (Figure 2a,b). In the case of SCOPUS, the number of publications increased from two in 2008 to 23 in 2012 (PROV-E) and from three in 2008 to 22 in 2012 (REG-E). In the case of ISI-Web of Science, the number of publications increased from one in 2008 to 12 in 2012 (PROV-E) and from two in 2008 to 12 in 2012 (REG-E). A similar trend was observed when using "provisioning services" AND "forests" OR "forest ecosystems" (PROV-FE) and "regulating services" AND "forests" OR "forest ecosystems" (REG-FE) as search strengths (Figure 2c,d). In the case of SCOPUS, the number of publications increased from one in 2008 to six in 2011 (PROV-FE) and from one in 2008 to five in 2011 (REG-FE). In the case of ISI-Web of Science, the number of publications increased from one in 2008 to four in 2011 (PROV-FE) and from one in 2008 to three in 2011 (REG-FE). After 2011, there was a decline in the number of publications, down to four (both PROV-FE and REG-FE) for SCOPUS and down to one (PROV-FE) and five (REG-FE) for ISI-Web of Science. Considering the "biodiversity services" OR "habitat services" OR "supporting services" AND "ecosystems" (BIO-E) and "cultural services" OR "aesthetic services" OR "amenity services" OR "tourism services" OR "recreational services" AND "ecosystems" (CULT-E) search strengths, the results show that the number of publications generally increased from 2005 to 2012 (with different trends during this period) for both SCOPUS and ISI-Web of Science (Figure 2a,b). In particular, the number of publications for BIO-E increased from one in 2005 to 14 in 2012 (SCOPUS) and from zero in 2005 to seven in 2012 (ISI-Web of Science). CULT-E increased from three in 2005 to 40 in 2012 (SCOPUS) and from eight in 2005 to 93 in 2012 (ISI-Web of Science). A different trend was found for the "biodiversity services" OR "habitat services" OR “supporting services” AND "forests" OR "forest ecosystems” (BIO-FE) and "cultural services” OR "aesthetic services" OR "amenity services" OR "tourism services" OR "recreational services" AND "forests" OR "forest ecosystems" (CULT-FE) search strengths (Figure 2c,d). In the case of BIO-FE, SCOPUS reported that the number of publications fluctuated from zero to four in 2005 to 2008 (only one publication was released in 2004) and then from five to one in the 2010 to 2012 period. A different trend regarding the number of publications was registered by ISI-Web of Science for BIO-FE: from zero to five (2005 to 2008) and from two to six (2010 to 2012). In the case of CULT-FE, the number of publications generally increased from zero to nine (SCOPUS) and nine to 45 (ISI-Web of Science) from 2005 to 2012.

\subsubsection{Section 4-Ecosystem Services in Italy}

Figure 3 shows the publications grouped per TA for the "forest ecosystem services" AND "Italy" (ES-IT) and "ecosystem services" AND "forests" AND "Italy" (ES-F-IT) search strengths. No results were found for "forest ecosystem services" AND "Italy".

For Review Section 4, the total number of publications in the 2000 to 2012 period was 25 (for "ecosystem services" AND "Italy" search strength; ES-IT) and eight (for "ecosystem services" AND "forests" AND "Italy"; ES-F-IT) (SCOPUS; Figure 3a). In the case of ISI-Web of Science, the total number of publications in the 2000 to 2012 period was 20 (ES-IT) and 2 (ES-F-IT) (ISI-Web of Science; Figure $3 b$ ). By analyzing the main contents, the consistency of each publication with the related TA can be summarized as follows: (i) most publications focus on the "ES assessment" TA (nine for ES-IT and 
three for ES-F-IT in the case of SCOPUS; seven for ES-IT in the case of ISI-Web of Science); (ii) very few publications focus on "The economics of ES" (one and one for ES-IT and two and one for ES-F-IT in SCOPUS and ISI-Web of Science, respectively) and "ES and local communities" TAs (one and two for ES-IT and one and one for ES-F-IT in SCOPUS and ISI-Web of Science, respectively); (iii) no publication for ES-F-IT was found for the "ES and LUCC" TA in either SCOPUS or ISI-Web of Science.

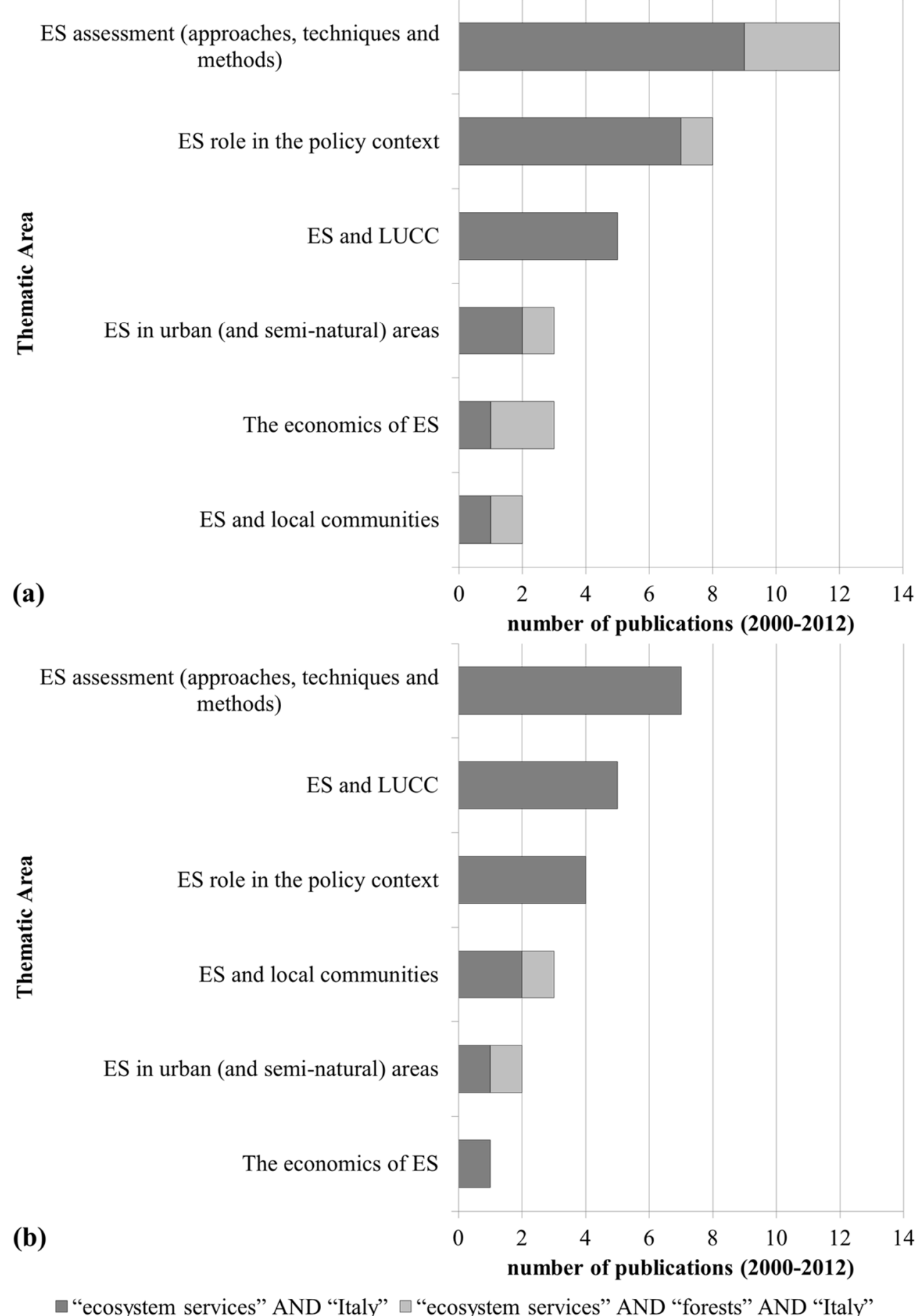

Figure 3. Number of publications per TA as found in Review Section 4 for SCOPUS (a) and ISI-Web of Science (b). 
Table 4. List of surveyed National and Regional Parks. Information has been reported by the respondents in Section 1 of the questionnaire.

\begin{tabular}{|c|c|c|c|c|c|c|c|c|}
\hline Park Name & $\begin{array}{c}\text { IUCN } \\
\text { Classification }\end{array}$ & $\begin{array}{l}\text { Covered } \\
\text { Regions }\end{array}$ & $\begin{array}{l}\text { Covered } \\
\text { Provinces }\end{array}$ & $\begin{array}{c}\text { Covered } \\
\text { Municipalities }\end{array}$ & $\begin{array}{l}\text { Total } \\
\text { Area }\end{array}$ & $\begin{array}{c}\text { Forest } \\
\text { Area } \\
(\%)\end{array}$ & $\begin{array}{l}\text { Managed } \\
\text { Forest } \\
\text { Area }(\%)\end{array}$ & $\begin{array}{l}\text { Main Forest } \\
\text { Category }\end{array}$ \\
\hline $\begin{array}{l}\text { "Pineta di Appiano Gentile e Tradate" Park [Parco Pineta di } \\
\text { Appiano Gentile e Tradate] }\end{array}$ & $\mathrm{Ib}$ & 1 & 2 & 15 & 4828 & 0.72 & 1.000 & $\begin{array}{l}\text { Scots pine and black } \\
\text { pine forests }\end{array}$ \\
\hline "Mont-Avic" Natural Park [Parco Naturale Mont Avic] & $\mathrm{Ib}$ & 1 & 1 & 2 & 5800 & 0.28 & 0.000 & $\begin{array}{l}\text { Scots pine and black } \\
\text { pine forests }\end{array}$ \\
\hline "Vesuvio" National Park [Parco Nazionale del Vesuvio] & II & 1 & 1 & 13 & 8482 & 0.44 & 0.541 & $\begin{array}{l}\text { Coniferous } \\
\text { plantations }\end{array}$ \\
\hline $\begin{array}{l}\text { "Prealpi Giulie" Natural Park [Parco Naturale delle Prealpi } \\
\text { Giulie] }\end{array}$ & $\mathrm{Ib}$ & 1 & 1 & 6 & 9402 & 0.49 & 0.782 & $\begin{array}{l}\text { European beech } \\
\text { forests }\end{array}$ \\
\hline $\begin{array}{l}\text { Aurunci mountains Natural Park [Parco Naturale dei Monti } \\
\text { Aurunci] }\end{array}$ & $\mathrm{Ib}$ & 1 & 2 & 10 & 19,374 & 0.59 & 0.947 & $\begin{array}{l}\text { Hop-hornbeam and } \\
\text { flowering ash mixed } \\
\text { forests }\end{array}$ \\
\hline $\begin{array}{l}\text { "Dolomiti Bellunesi" National Park [Parco Nazionale delle } \\
\text { Dolomiti Bellunesi] }\end{array}$ & II & 1 & 1 & 15 & 32,000 & 0.69 & 1.000 & $\begin{array}{l}\text { European beech } \\
\text { forests }\end{array}$ \\
\hline $\begin{array}{l}\text { "Foreste Casentinesi, Monte Falterona, e Campigna" National } \\
\text { Park [Parco Nazionale delle Foreste Casentinesi, Monte } \\
\text { Falterona e Campigna] }\end{array}$ & II & 2 & 3 & 10 & 36,800 & 0.87 & 0.781 & $\begin{array}{l}\text { European beech } \\
\text { forests }\end{array}$ \\
\hline $\begin{array}{l}\text { "Abruzzo, Lazio e Molise" National Park [Parco Nazionale } \\
\text { d'Abruzzo, Lazio e Molise] }\end{array}$ & II & 3 & 3 & 24 & 50,000 & 0.58 & 0.655 & $\begin{array}{l}\text { European beech } \\
\text { forests }\end{array}$ \\
\hline Adamello Natural Park [Parco Naturale dell'Adamello] & $\mathrm{Ib}$ & 1 & 1 & 18 & 51,000 & 0.46 & 0.062 & $\begin{array}{l}\text { Other broadleaved } \\
\text { forests }\end{array}$ \\
\hline Adamello-Brenta [Parco Naturale Adamello-Brenta] & $\mathrm{Ib}$ & 1 & 1 & 40 & 62,050 & 0.81 & 1.000 & $\begin{array}{l}\text { Norway spruce } \\
\text { forests }\end{array}$ \\
\hline $\begin{array}{l}\text { "Monti Sibillini” National Park [Parco Nazionale dei Monti } \\
\text { Sibillini] }\end{array}$ & II & 2 & 4 & 19 & 69,439 & 0.42 & 0.956 & $\begin{array}{l}\text { European beech } \\
\text { forests }\end{array}$ \\
\hline "Majella" National Park [Parco Nazionale della Majella] & II & 1 & 3 & 39 & 74,100 & 0.66 & NA & $\begin{array}{l}\text { European beech } \\
\text { forests }\end{array}$ \\
\hline "Gargano" National Park [Parco Nazionale del Gargano] & II & 1 & 1 & 18 & 121,400 & 0.52 & 1.000 & $\begin{array}{l}\text { European beech } \\
\text { forests }\end{array}$ \\
\hline "Stelvio" National Park [Parco Nazionale dello Stelvio] & II & 4 & 4 & 23 & 130,700 & 0.29 & 0.762 & $\begin{array}{l}\text { Norway spruce } \\
\text { forests }\end{array}$ \\
\hline "Pollino" National Park" [Parco Nazionale del Pollino] & II & 2 & 3 & 56 & 192,000 & 0.58 & 0.140 & $\begin{array}{l}\text { European beech } \\
\text { forests }\end{array}$ \\
\hline
\end{tabular}




\subsubsection{Review Section 5-Projects in the Context of Ecosystem Services}

The results for Review Section 5 can be summarized as follows: (i) since 2000, the total number of EU-funded projects focused on ES-related topics and, in particular, FES is 68 (29\% to be concluded after 2012); (ii) Italy is included in 24 of the project consortia (coordinator in three of them); and (iii) $25 \%$ of the projects have specific objectives and activities correlated with the FES topic, whether totally or partially $(10.3 \%$ and $14.7 \%$, respectively). For detailed results, the reader is referred to Supplementary 2.

\subsection{Implementation of FES}

\subsubsection{General Information}

Questionnaires were filled out by the managers or technical personnel employed at the 15 selected NRPs in Italy. The related characteristics (see Table 4) demonstrate that the selection criteria were fulfilled in terms of the Regions represented and forest area covered.

The following insights can be obtained from the results of section 1: (i) the total surveyed area is $31.4 \%$ of the total NRP area (867,375 ha vs. $2,760,337$ ha); (ii) the total surveyed forest area is 471,181 ha, which is $4.5 \%$ of the total forest area in Italy; and (iii) the average forest area is approximately $56 \%$ of the total PAN, of which $69 \%$ is managed (completely managed for $31 \%$ of NRPs). From the administration point of view, the NRP selection included more than $72 \%$ of the total number of regions and autonomous provinces in Italy.

3.2.2. What is the Relevance of Forest Ecosystem Services within Protected Areas?

Figure 4 shows the relevance of FES in NRPs, as resulted from Section 2 of the questionnaires.

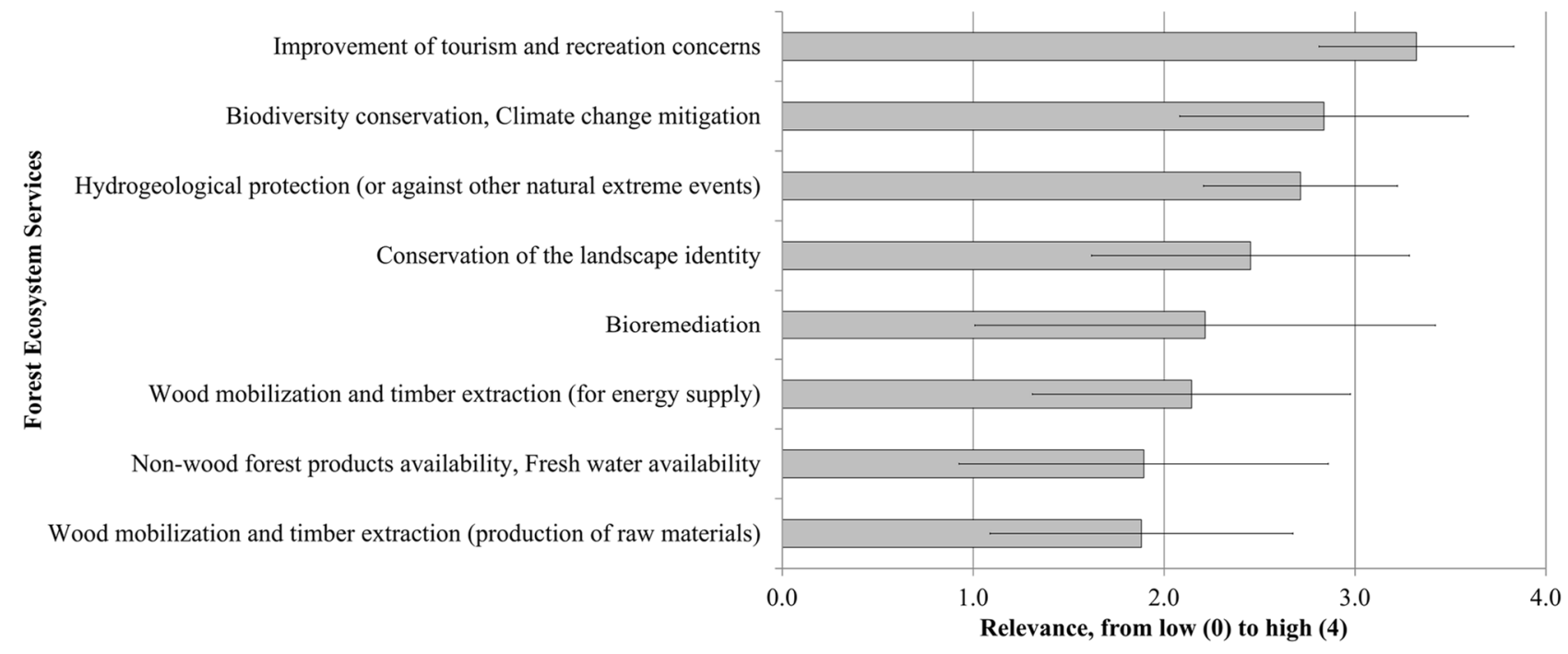

Figure 4. Bar chart reporting the Forest Ecosystem Services (FES) relevance (grouped by Division) in surveyed NRPs. Relevance values vary from very low (0) to very high (4). Bars refer to Standard Deviation (SD) values. 
For the FES relevance survey, the $t$-test shows the following: (i) the improvement of tourism and recreation services is considered of average importance $(3.3 \pm 0.51)$ but shows higher relevance than, e.g., the provision of raw materials (wood and fiber, among the others) $(1.9 \pm 0.79)(p<0.01)$; (ii) the enhancement of interactions with forest ecosystems (here defined as conservation of the landscape identity) is considered less important $(2.5 \pm 0.83)$ than, e.g., the improvement of tourism and recreation services $(3.3 \pm 0.51)(p<0.01)$; (iii) the maintenance of ecosystem processes and functions (including biodiversity conservation and habitat protection) is considered more important (2.8 \pm 0.76$)$ than, e.g., the availability of non-wood forest products $(1.9 \pm 0.97)(p<0.01)$, wood mobilization and timber extraction for energy purposes $(2.1 \pm 0.83)(p<0.01)$, and bioremediation $(2.2 \pm 1.21)(p<0.01)$; (iv) hydrogeological protection and bioremediation are considered less important $(2.7 \pm 0.51$ and $2.2 \pm 1.21$, respectively) than the improvement of tourism and recreation services $(3.3 \pm 0.51)(p<0.05$ and $p<0.01$, respectively); and (v) biomass-based energy sources are considered less important $(2.1 \pm 0.83)$ than, e.g., hydrogeological protection $(2.7 \pm 0.51)(p<0.05)$.

High variability in the results indicates the relevance values of the bioremediation services $(\mathrm{SD}=1.20)$, non-wood forest products, and fresh water availability $(\mathrm{SD}=0.93)$. Low variability indicates the relevance values of both hydrogeological protection and the improvement of tourism and recreation concerns ( $\mathrm{SD}=0.51$ for both). These aspects demonstrate the following: (i) most likely, there was a partial lack of knowledge (or misunderstanding) of some of the ES definitions, particularly regarding forests, when assessing their relevance; and (ii) some of the ESs were not always considered primarily forest services and were thus not assessed in the same way by all the respondents.

\subsubsection{How Do Stakeholders Influence Forest Ecosystem Services Provision?}

Figure 5 reports the impacts of different stakeholder typologies on the whole set of FESs (Section 3 of the questionnaire).

The results from Section 3 of the questionnaire reveal the following: (i) nature conservationists such as NGOs, the European Union, the Park Authority, and other public bodies have a positive impact on the whole set of FESs, ranging from 0.28 for the availability of non-wood forest products and fresh water to 0.64 for the conservation of landscape identity; (ii) agriculture and pasture have few positive impacts (e.g., on non-wood forest products and fresh water availability, 0.38) and more negative impacts, especially on bioremediation $(-0.26)$ and biodiversity conservation and climate change mitigation $(-0.12)$; (iii) the tourism sector plays a positive role for all FESs, especially regarding the improvement of tourism and recreation concerns (approximately 0.56 ); (iv) the forestry sector generally has no impact on FESs at all, thus registering the highest positive values for the production of raw materials (0.48) and biomass-based energy supply (0.40); (v) recreational activities (such as hunting, mushroom picking, and skiing) are generally seen as relatively negative influencing factors on FES provision (between -0.07 and -0.17 for most FESs); (vi) education and research activities are considered the most influencing drivers for improving FES provision, with values ranging from 0.46 (production of raw materials and biomass-based energy supply) to 0.87 (improvement of tourism and recreation concerns); (vii) public institutions (intended here as Army-related activities) are considered limiting factors for FES provision (e.g., -0.36 for bioremediation); (viii) local users and farmers, on average, have no impact on FES provision (the values are approximately 0 for all FESs); (ix) local inhabitants are seen as drivers of FES 
provision, especially regarding the improvement of tourism and recreation services and the conservation of landscape identity ( 0.58 for both); and (x) the manufacturing sector is the most negative influencing factor (i.e., the most limiting agent) for the FES provision, with values ranging from -0.05 for biomass-based energy supply to -0.52 for biodiversity conservation and climate change mitigation.
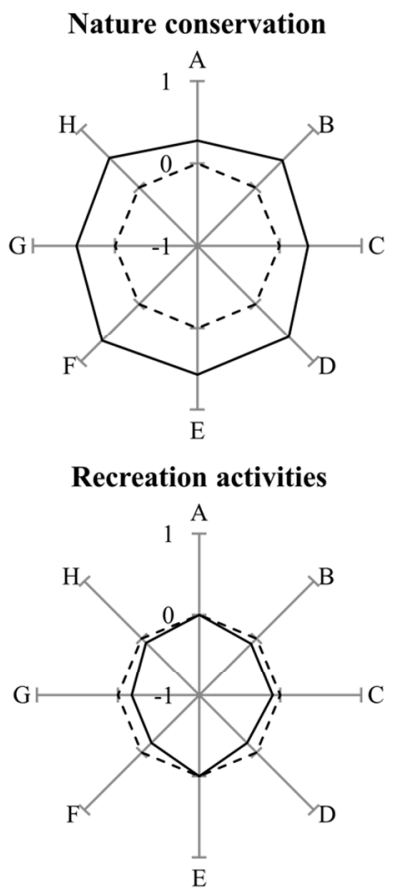

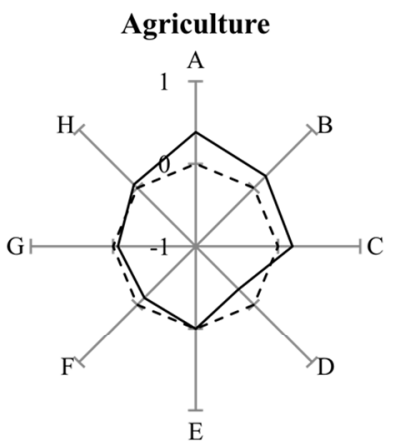

Education and research

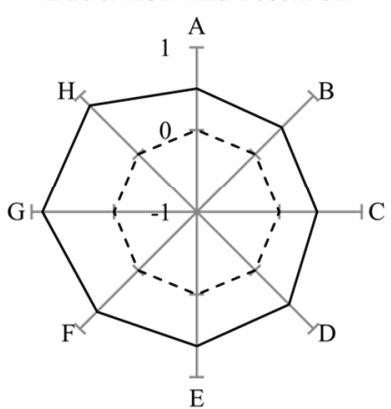

Local inhabitants

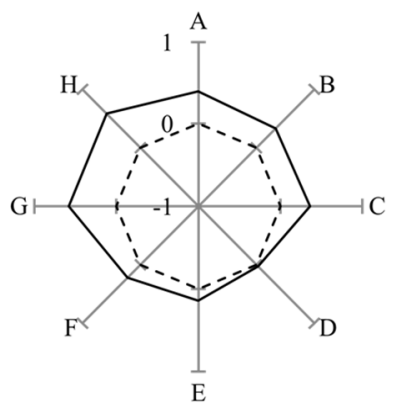

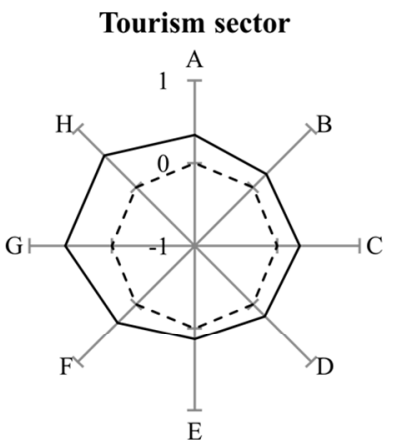

Public Institutions

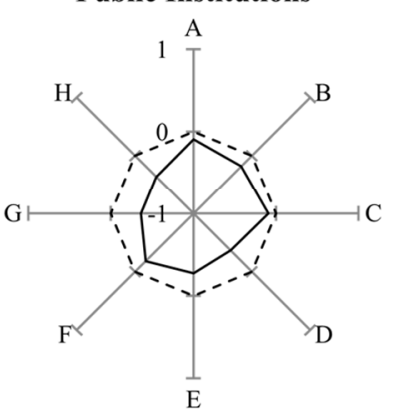

Manufacturing sector

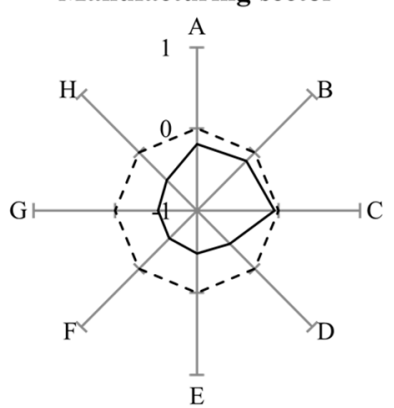

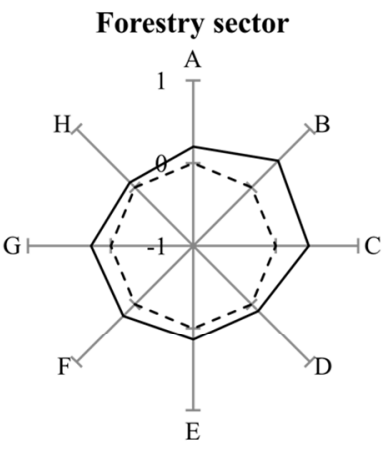

Users and consumers

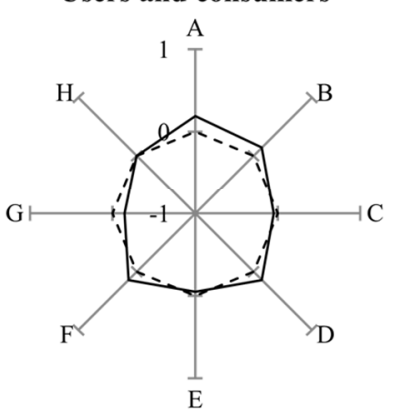

Figure 5. Spider charts showing the different impacts of stakeholder typologies (top of the charts) on FES. Impacts are represented by solid lines, and related values range between -1 (negative) to 1 (positive). No impact corresponds to 0 value. Impacted services are lettered on chart's crowns as follows: non-wood forest products/fresh water availability (A); Production of raw materials (B); Timber extraction for energy supply (C); Bioremediation (D); Hydrogeological protection (E); Biodiversity conservation and climate change mitigation $(\mathrm{F})$; Improvement of tourism and recreation concerns $(\mathrm{G})$; and Conservation of the landscape identity $(\mathrm{H})$. See Table 2 for calculations and Annex 1 for nomenclature.

\subsubsection{What Are the Main Governance Instruments at Work in Protected Areas?}

The results from Section 4 of the questionnaire show that some of the most important governance instruments regarding biodiversity conservation (gen. nature conservation) and FES provision are at work in more than $50 \%$ of the cases. Downscaled by implementation level, these instruments are "EU 
regulatory frameworks" (93\% of respondents), "Regional Forest Law" (86\% of respondents), and "Regional Forest Plan" (64\% of respondents); "Watershed Plan" (71\% of respondents) and "Forest Landscape Management Plan" (50\% of respondents); and "Management and Conservation Plan" (71\% of respondents). On the other hand, other important governance instruments, such as "National Strategies and Forest Action Plans", "Forest Certification Instruments", and "Eco-labels for local agricultural products" are not yet widely available or implemented $(36 \%, 29 \%$, and $29 \%$ of respondents, respectively).

\subsubsection{What Are the Main Factors Influencing Forest Management with the Objective of} Services Provision?

Figure 6 shows the results regarding the roles of different factors (e.g., local stakeholders, FES analysis) in decision-making processes and forest management concerns (Section 5 of the questionnaire).

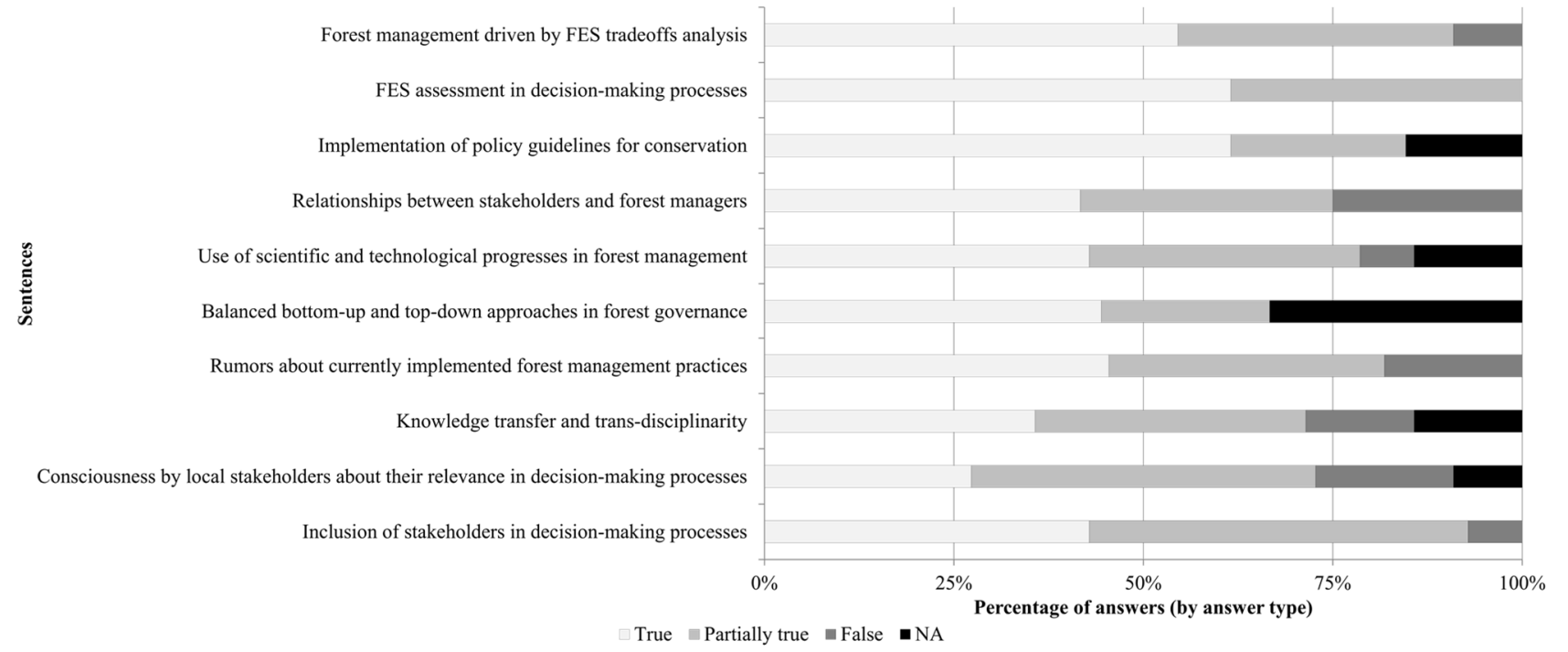

Figure 6. Bar chart showing the relative percentage of respondents to several sentences regarding the role of different factors (local stakeholders, FES analysis, etc.) in decision-making processes in surveyed NRPs.

The results from Section 5 of the questionnaire can be summarized as follows: (i) FES assessment is included in decision making processes, and analysis of their tradeoffs is considered in implementing forest management (true for $62 \%$ and $55 \%$ of respondents, respectively); (ii) nature conservation is implemented by adopting specific policy guidelines (true for $62 \%$ of respondents); (iii) stakeholders are partially engaged in decision-making processes (true for $43 \%$ of respondents), for which they are not recognized as relevant (see "Local stakeholders' perception about their relevance in decision-making processes", which is true for $27 \%$ of respondents), and they have rather few relationships with forest managers (true for $42 \%$ of respondents); (iv) bottom-up and top-down approaches in forest governance are not completely balanced (true for $44 \%$ of respondents); (v) knowledge-transfer and trans-disciplinarity are generally lacking (true for $36 \%$ of respondents); and (vi) scientific and technological progress or advances are not always taken into account in forest management (true for $43 \%$ of respondents). These results have a high level of uncertainty. In fact, the "False/Not Available (NA)" answers correspond to $13 \%$ of respondents, on average. Moreover, the "Partially true" answers (36\% of respondents, on 
average) do not offer more details allowing a deeper analysis of the results (or of the differences regarding the "True" answers).

The results from Section 5 of the questionnaire yield the following insights: (i) although FESs are assessed for decision-making objectives and their trade-offs are considered while managing forests (see Figure 6), there is no specific information about the level of detail in quantifying FESs, the methodologies applied, or the quality of data used for such purposes (see Supplementary 1, Section 5); (ii) stakeholders are not especially involved in decision-making processes, so they do not consider their opinions as relevant for forest management; and (iii) there is not always a good balance between the top-down and bottom-up approaches (see Figure 6).

\subsubsection{How Are Research Activities and Outcomes Used for Managing Forest Ecosystem}

Service Provision?

Figure 7 shows how the research is linked to the management of forests and their services within the surveyed NRPs.

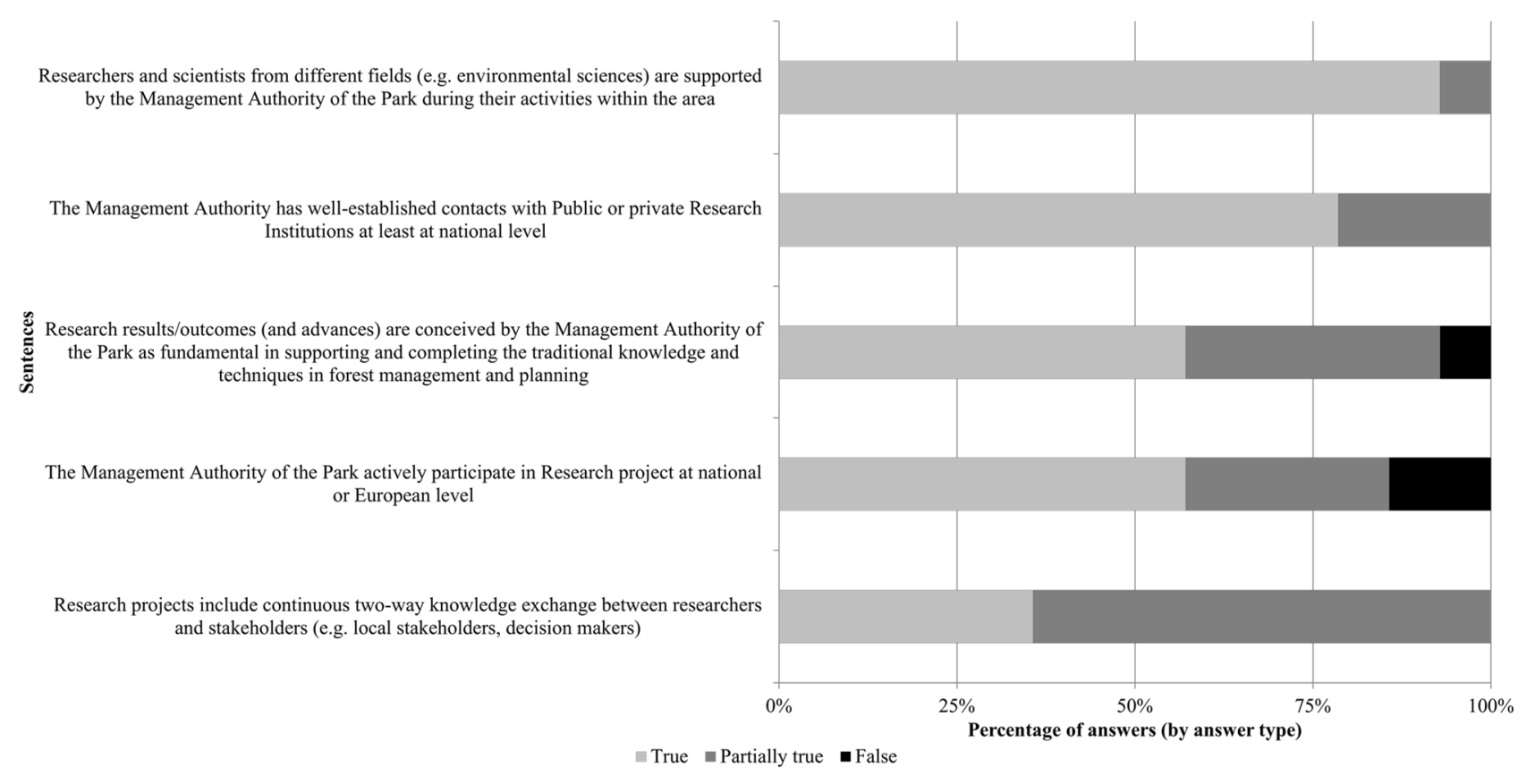

Figure 7. Bar chart showing the relative percentage of respondents to several sentences regarding the role of research (related activities, results and advances) in decision-making processes in surveyed NRPs.

The results from Section 6 of the questionnaire can be summarized as follows: (i) authorities support researchers and their activities within the NRPs (true for $92 \%$ of respondents), they are in cooperation with several research bodies at the national level (true for $78 \%$ of respondents), and they participate in different research projects (true for $57 \%$ of respondents); (ii) although the authorities perceive the support of research outcomes to be essential for improving practical forest management (true for 57\% of respondents), research projects do not consider the two-way exchange between stakeholders and decision-makers (true for $35 \%$ of respondents). 
3.2.7. How Does Current Management Ensure Forest Ecosystem Service Provision in Protected Areas?

Figure 8 reports the ranking of three important FES-Forest Management linkages (Section 7 of the questionnaire): (i) priority for management guidelines, (ii) difficulty in quantifying and valuing the service, and (iii) relevance for local communities (in terms of expected benefits).

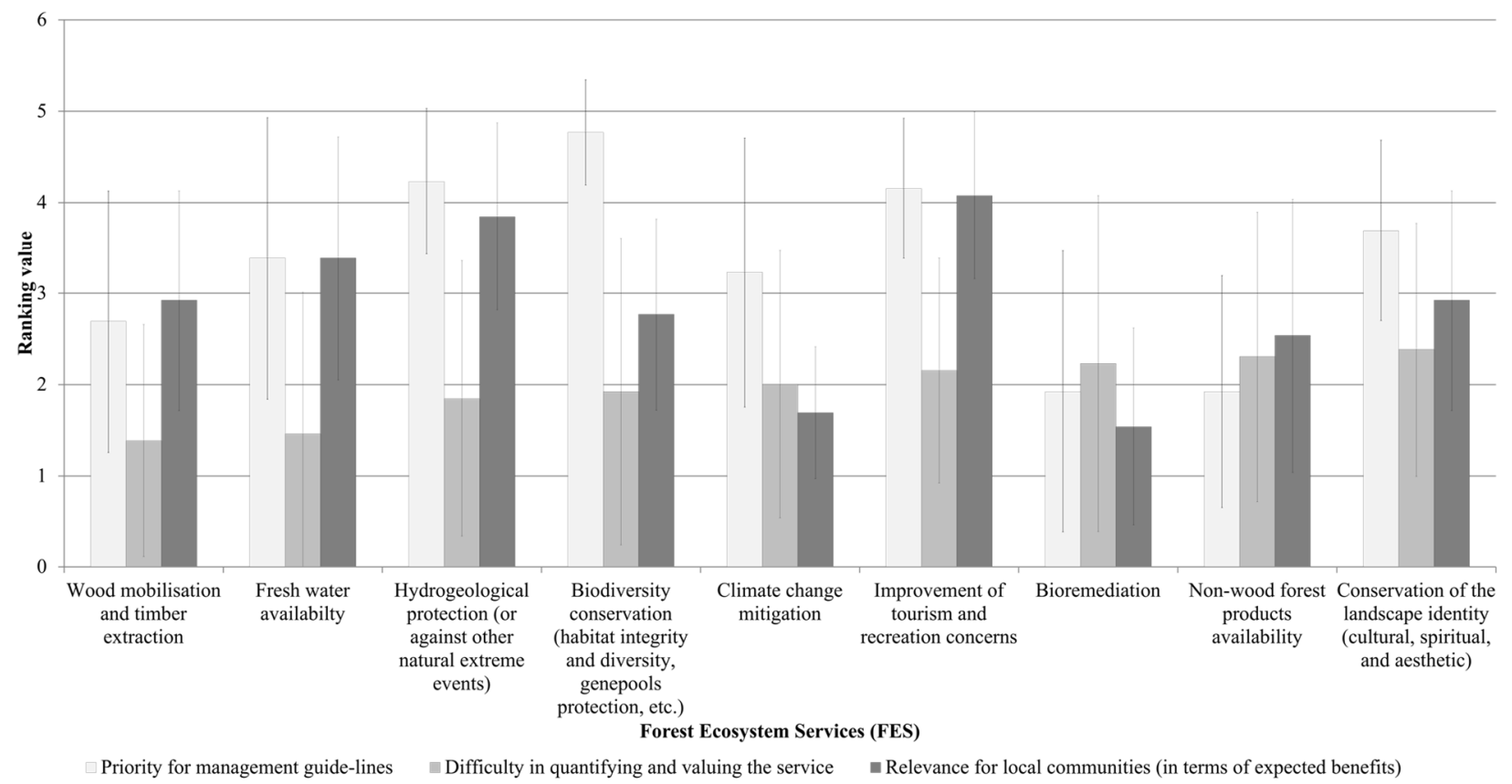

Figure 8. Bar chart reporting the ranking values o of priority, difficulty and relevance of each FES for forest management. Bars represent the Standard Deviation (SD) values.

Concerning the priority for management guidelines, the $t$-test shows the following: biodiversity conservation has higher priority $(4.76 \pm 0.57)$ than, e.g., the conservation of landscape identity $(3.69 \pm 0.99)(p<0.01)$; hydrogeological protection has higher priority $(4.23 \pm 0.79)$ than, e.g., wood mobilization and timber extraction $(2.69 \pm 1.43)(p<0.01)$; and the improvement of tourism and recreation services has higher priority $(4.15 \pm 0.76)$ than, e.g., bioremediation $(1.92 \pm 1.54)(p<0.01)$. Meanwhile, non-wood forest products availability and bioremediation services show lower priority (1.92 \pm 1.26 and $1.92 \pm 1.54$, respectively) than, e.g., biodiversity conservation $(4.77 \pm 0.58)$ and hydrogeological protection $(4.23 \pm 0.80)(p<0.01)$. The improvement of tourism and recreation services is considered more relevant for local communities $(4.07 \pm 0.91)$ than, e.g., wood mobilization and timber extraction $(2.92 \pm 1.20)(p<0.05)$, biodiversity conservation $(2.76 \pm 1.04)(p<0.01)$, and conservation of landscape identity $(2.92 \pm 1.20)(p<0.05)$. In contrast, bioremediation shows lower relevance for local communities $(1.58 \pm 1.08)$ than, e.g., fresh water availability $(3.38 \pm 1.33)$, hydrogeological protection $(3.84 \pm 1.02)$, and climate change mitigation $(1.69 \pm 0.72)(p<0.01)$.

Considering the difficulty in quantifying and valuing the services, the respondents gave very low ranking values. These results indicate that it is not difficult to have a quantitative or qualitative assessment of a given FES, including its economic evaluation. For example, the conservation of landscape identity was ranked as the most difficult of the assessed FESs. Of course, this element 
(i.e., "relevance") shows a higher variability (SD between 1.23 and 1.84) compared with "priority" (SD between 0.57 and 1.54) and "difficulty" (SD between 0.72 and 1.49).

\section{Discussion}

\subsection{Issues at Stake in FES Research}

Taking into account the limitations of our review exercise (i.e., lack of information concerning the impact of research contributions to the topic of forest ecosystem services), the results from review Section 1 demonstrate poor integration of knowledge on FESs within adaptive governance at the local level, including scientific concepts in forest management strategies. Despite the increasing global awareness among scientists of the importance of ESs since the Millennium Ecosystem Assessment release in 2005 (as also noted by [49,50]), our review reveals that the number of publications on FESs has been relatively stable (see Figure 1). Although we found a certain variability concerning the number of publications between the SCOPUS and ISI-Web of Science search engines, the results show similar trends. Moreover, there were 10 times fewer FES-related publications compared with those obtained when considering "ecosystem services" and "ecosystem services and forests" (see Figure 1). This indicates that the role of forests in the ES framework has not been completely treated, is not widespread, and is not even considered of primary importance. Review Sections 2 and 3 show that cultural services (CULT-E and CULT-FE) are treated in a relatively high number of publications (nearly double that of the other service categories) (see Figure 2). This is partially explained by the fact that cultural services have gained more attention over the last few years (see, e.g., [51-53]). This inconsistency between the search strength and the obtained results may depend on the level of detail of the used keywords as well as the search engine itself. Generally, ISI-Web of Science produced a larger amount of results compared with SCOPUS for two reasons: in the first case, keywords were searched within the "topic" field, while in the second case, they were searched for within the "abstract, title, and keywords" fields. Therefore, the unstructured results by service type may be due to the tendency to treat different services as integrated parts of a "whole group". The results available for each service category may help identify the trans-disciplinary role of forest resources, ranging from the socio-economic to the biophysical to the policy and planning contexts (e.g., [54]). This is the case, e.g., for biodiversity, which is a key term in ES and FES contexts. Compared with other service categories, biodiversity conservation is specifically addressed in 14\% (SCOPUS) and 6\% (ISI-Web of Science) of publications. In the case of forests, biodiversity conservation is treated in 5.5\% (SCOPUS) and 10.5\% (ISI-Web of Science) of publications. Regarding forest resources, Thompson et al. [55] reported that $76 \%$ of the 21 reviewed studies showed a direct relationship between increased biodiversity (measured as tree and understory species richness) and increased primary productivity. Similarly, Thompson et al. and Balvanera et al. [55,56] confirmed that plant diversity enhances belowground plant and microbial biomass and decomposer activity and diversity, resulting in greater diversity of primary consumers and a lower number of invasive species relative to systems with low levels of productivity. In addition, Gamfeldt et al. [57] found consistent positive relationships between tree species richness (contrasting plots with five and one tree species) and multiple ESs, thus confirming that the conservation of forest stand diversity is needed to safeguard the future potential of high levels of multiple ESs (for further examples, see [58]). Cardinale et al. [29] 
outlined two important directions to be undertaken: (i) detailing the mechanistic links between ecosystem functions and services; and (ii) developing theoretical approaches that can link small-scale research (mechanistic focus of biodiversity and ecosystem functioning) to the large-scale patterns that are the focus of biodiversity and ESs.

Taking into account the results from Review Section 5, research projects that entirely focus on the FES topic are still rare at the continental scale (see Supplementary 2). Indeed, some important European research pathways regarding the ES topic were not found through RS E. Such is the case, for example, of the RUBICODE ("Rationalizing Biodiversity Conservation in Dynamic Ecosystems", at: www.rubicode.net) project, which ended in 2009. RUBICODE reviewed information on ESs for the main terrestrial and freshwater ecosystems in Europe and provided an operative framework to rationalize biodiversity conservation strategies ([59,60]). Therefore, since the "EU Biodiversity Strategy" [31], the importance of mapping and assessing ESs has gained more attention among scientists, up to the establishment of the MAES (Mapping and Assessment of Ecosystems and their Services) Working Group, with the main purpose of supporting Member States in fulfilling the requirements of Action 5 "Action 5 of the EU Biodiversity Strategy requires Member States, with the assistance of the Commission, to map and assess the state of ecosystems and their services in their national territory by 2014 , assess the economic value of such services, and promote the integration of these values into accounting and reporting systems at EU and national level by 2020" of the "EU Biodiversity Strategy" [61]. Italy was not involved in the pilot study phase (up to the end of 2014). Of course, RSE does not currently consider FES-related projects underway at the national level in Italy. However, a deeper analysis indicates that several FES projects are in fact currently underway at the national level in Italy. Some examples are as follows: (i) the INTEGRAL ("Integrated Management of European Forest Landscapes"; at: www.integral-project.eu) project, which specifically aims to diminish the discrepancies between policy and management approaches to improve the potential of European forest landscapes to deliver multiple services and to provide management guidelines according to the ecological and socio-economic contexts; (ii) the MIMOSE ("Development of innovative models for multiscale monitoring of ES indicators in Mediterranean forests") project, which aims to build and implement a set of spatially explicit indicators for mapping and valuing ESs in the Mediterranean area [62]; and (iii) the LIFE+ MGN ("Making Good Natura"; at: www.lifemgn-serviziecosistemici.eu) project, which aims to develop innovative approaches to environmental governance to preserve agro-forest-ecosystems and to establish instruments for the qualitative and quantitative valuation of ESs in the study sites of the Natura2000 Network.

Considering the above-mentioned issues and the recent enormous efforts by the EU (e.g., [63]) and its Member States to implement the ES approach within development strategies, Italy does not yet have its own proposal [64]. Thus far, the applied research on forests and other ecosystems (including the services they provide) has suffered from the scarcity of available data; the fragmentation and differentiation of both on-the-ground and remotely sensed information; the weakness of trans-disciplinary cooperation among universities, national research institutes, and local administrative bodies at the national level; and the notable reduction of economic investments in research, innovation, and development $(-1.6 \%$ between 2011 and 2012; [65]). 


\subsection{Issues at Stake in Managing Forests for Services Provision}

The conservation of biodiversity, the improvement of tourism and recreation services, and hydrological protection are the most relevant FESs both for forest management purposes and local community needs (see Figure 4). They also have the highest priorities toward effectively implementing management guidelines (see Figure 8). These results may depend on the following factors: (i) biodiversity conservation is the primary objective of the Protected Areas establishment, taking into account its key role both in Italy [66] and globally [67]; (ii) the tourism sector and recreation activities are two of the key economic drivers for improving the wellbeing of people living within the Protected Areas boundaries (see, e.g., [68]); and (iii) the regulation of hydrological regimes to protect human infrastructures against floods, runoff erosion, avalanches, or other natural hazards is one of the most important forest functions, especially if regulated by specific laws and restrictions, as in Italy [69]. However, the provision of timber, fiber, and other forest products is considered less relevant (see Figure 4). This is partially because most of the regulatory frameworks of the NRPs in Italy strictly limit the use of forest resources for economic purposes (including timber extraction and transformation), at least in their core areas for biodiversity conservation (see [33]). In this sense, our results confirm that although provisioning services generate economic benefits for local populations living in the Mediterranean area (for a complete review, see [70]), they are generally in conflict with other services, especially with biodiversity conservation (see, e.g., [71]). In practice, management can be better implemented by adopting an integrated approach that takes into account economic, socio-cultural, and ecological features (e.g., areas for commercial use $v s$. areas for nature conservation). In this way, less obvious services for the current state of local conditions can also be valorized in the future (e.g., bioremediation, hydrogeological protection).

Although the NRP management authorities use research activities to support biodiversity monitoring and forest management for ES maximization, there is no knowledge transfer to local communities (see Figure 7). This means research outcomes and advances are not delivered to and shared with people, such as stakeholders or inhabitants, despite "education and research" being considered the most positive drivers for FES provision (see Figure 5). Through participatory events, the research community can communicate FES values and trends within an economic context to local managers and stakeholders to increase the awareness of the importance of preserving natural capital. On the other hand, NRP management authorities should encourage these events and make more efforts to involve local stakeholders in forest management decisions. Understanding the role stakeholders play in management and FES provision is extremely important because of the value of ESs in relation to their views and needs [72] and because such provision improves the human-environmental system relationship (e.g., [73]). Moreover, adaptive forest management properly builds on the sharing of management responsibility among different sets of stakeholders operating at different levels [74]. From the results in Figure 5, it is clear that the relationship between local stakeholders and the provision of FESs depends on at least two main factors: (i) the identified stakeholder typology (public bodies, inhabitants, and private companies) and (ii) the stakeholder's behavior with regard to FES provision (provider or consumer, source or beneficiary). Regarding the stakeholder typology, the "nature conservation", "education and research", "tourism", and "forestry" sectors show the highest positive influences (seen as public bodies and institutions), especially regarding biodiversity conservation, habitat integrity, and the maintenance of the cultural and spiritual values of FESs. However, inhabitants and private companies 
are seen as impacting FES provision. Regarding stakeholder behavior, the providers ("nature conservation" and "education and research") are obviously considered drivers of FES availability. However, the users (i.e., "local inhabitants", "recreation activities", and the "manufacturing sector") are considered barriers to FES availability. The negative influence of stakeholders on FES provision may be reduced through adopting specific regulatory frameworks and economic incentives to compensate for the provision of certain fundamental services (e.g., biodiversity conservation, climate change mitigation) (i.e., Payment for Environmental Services).

Our results confirm that forest management for maximizing biodiversity conservation and services provision in Protected Areas in Italy needs to be effectively implemented, except for some positive examples (e.g., [75]). Through a comparison with other Countries (e.g., [76]), our results demonstrate that forest management in Protected Areas in Italy mainly suffers from: (i) the scarcity of funding (in terms of level and security), which underlies many other issues; (ii) the undersupply of tangible benefits to local communities (i.e., effective visitor and tourism management); and (iii) the absence of specific natural resource management activities and/or meaningful management plans. As a consequence, adequate solutions should be found in order to safeguard benefits from forest resources, especially in Protected Areas, where impacts from external drivers are strongly reduced (see also [77]). In Italy, as also outlined by [78], management priorities in Protected Areas should be oriented to: (i) maintain and conserve biological diversity, through balancing with alternative services; (ii) preserve landscape heritage; (iii) promote tourism and recreation opportunities; and (iv) bridge the gap between academic and traditional knowledge, especially regarding forestry activities.

\section{Conclusions}

In conclusion, our review, which focused on literature and projects, offers the opportunity to deeply understand the issues, future challenges, and current lack of information regarding FES-related research at the European and Italian levels. The fundamental role of forest ecosystems in improving human well-being needs to be better understood and investigated more deeply at the local level (e.g., the effects of forest bathing on human health), especially regarding the linkage among ecosystem processes, the services provided, and the whole environment. For example, the improvement of knowledge on FESs can be realized by concentrating research efforts on modeling and mapping ES fluxes (from sources to beneficiaries). Although this challenge generally concerns the entire scientific community at the global scale, it is particularly amplified within the Italian context. Indeed, our results demonstrate that, particularly within the context of FESs, there is a large gap (in terms of number of publications and level of participation in project consortia) between Italian contributions and those at the global level. Other challenges for FES research in Italy include improving the interchange of knowledge among researchers, scientists, experts, technicians, and local communities as well as effectively involving stakeholders' needs in decision-making processes. In particular, stakeholders have to be actively involved in several steps during research activities and at an earlier stage of FES assessment. This aspect can be further developed by enabling a bottom-up, community-centered approach in forest management. We conclude that forest management has to be built on the perceptions and needs of local communities and stakeholders through a bottom-up approach in decision-making processes (not currently underway, at least in NRPs). 
The survey of NRPs in Italy allowed an investigation into whether the current forest management is oriented toward biodiversity conservation and the maximization of FES provision. Considering that the human-induced effects on forest ecosystems and biodiversity have been largely proven, current forest management practices and silvicultural interventions should be translated from monetary-centered to more sustainable and holistic approaches. Especially in fragile and degraded forest environments (i.e., in mountain areas), forest management is called to ensure forest health, vitality, and stability over the long run, to maximize ecosystem functioning, and to provide the whole set of FESs. In Italy, PAN can play an active role in conserving forest biodiversity and preserving the delivery of all FESs. Having a large portion of the country under nature conservation regimes, PAN is particularly suitable when considering the human-induced effects of land use change at the expense of natural environments. However, what are the challenges outside Protected Areas? Searching for the best FES trade-offs requires the adoption of "resilience thinking" in forest management, which evolved from the concept of "sustainability" and "ecosystem-based" approaches.

In agreement with both the international and national commitments, the development of a National Ecosystem Assessment Framework in Italy - as already adopted in other countries around the world (see, e.g., [79,80]) - is urgently needed to better orient decisions within a sustainable framework, especially within the forest sector. This framework can be used to map and assess (both ecologically and economically) FESs at the local to national levels, thus contributing to the monitoring of biodiversity conservation and the resilience of forest ecosystems.

\section{Acknowledgments}

This project has received funding from the European Union's Seventh Programme for research, technological development and demonstration, under grant agreement No 282887 (INTEGRAL).

The authors gratefully acknowledge the three anonymous reviewers for their useful comments that improved an earlier version of the manuscript.

The authors wish to thank Bruno Lasserre for his support during the analysis of results, and all people contributed to the NRPs survey, in particular: Antonio Caola and Roberto Zoanetti (Parco Naturale Adamello-Brenta); Alessandro Ducoli (Parco Naturale dell'Adamello, Comunità Montana di Valle Camonica); Giuseppe Marzano and Maria Rosaria Perna (Parco Naturale dei Monti Aurunci); Benedetto Fiori and Gianni Poloniato (Parco Nazionale delle Dolomiti Bellunesi); Luca Santini and Carlo Pedrazzoli (Parco Nazionale delle Foreste Casentinesi, Monte Falterona e Campigna); Stefano Pecorella and Carmela Strizza (Parco Nazionale del Gargano); Franco Iezzi and Caterina Palombo (Parco Nazionale della Majella, Università degli Studi del Molise); Corrado Binel and Massimo Bocca (Parco Naturale Mont Avic); Mario Clerici and Carlo Vanzulli (Parco Naturale Pineta di Appiano Gentile e Tradate); Antonio Carrara and Carmelo Gentile (Parco Nazionale di Abruzzo, Lazio e Molise); Annibale Formica and Giuseppe De Vivo (Parco Nazionale del Pollino); Giulio Goi (Parco Naturale delle Prealpi Giulie); Wolfgang Platter and Daniele Bettini (Parco Nazionale dello Stelvio); Oliviero Olivieri and Paolo Salvi (Parco Nazionale dei Monti Sibillini); Gennaro Esposito and Paola Conti (Parco Nazionale del Vesuvio). 


\section{Author Contributions}

Matteo Vizzarri performed the ecosystem services review and substantially contributed to write the paper, Roberto Tognetti designed the case study on Protected Areas and interpreted the results, and Marco Marchetti contributed to discuss and evaluate the main contents.

\section{Conflicts of Interest}

The authors declare no conflict of interest.

\section{References}

1. Millennium Ecosystem Assessment (MA). Ecosystems and Human Well-Being: Synthesis; Island Press: Washington, DC, USA, 2005; p. 155.

2. Foley, J.A.; DeFries, R.; Asner, G.P.; Barford, C.; Bonan, G.; Carpenter, S.R.; Chapin, F.S.; Coe, M.T.; Daily, G.C.; Gibbs, H.K.; et al. Global consequences of land use. Science 2005, 309, 570-574.

3. Lindner, M.; Maroschek, M.; Netherer, S.; Kremer, A.; Barbati, A.; Garcia-Gonzalo, J.; Seidl, R.; Delzon, S.; Corona, P.; Kolström, M.; et al. Climate change impacts, adaptive capacity, and vulnerability of European forest ecosystems. For. Ecol. Manag. 2010, 259, 698-709.

4. Deng, X.; Li, Z.; Huang, J.; Shi, Q.; Li, Y. A revisit to the impacts of land use changes on the human wellbeing via altering the ecosystem provisioning services. Adv. Meteorol. 2013, 2013, 8.

5. Haberl, H.; Erb, K.H.; Krausmann, F.; Gaube, V.; Bondeau, A.; Plutzar, C.; Gingrich, S.; Lucht, W.; Fischer-Kowalski, M. Quantifying and mapping the human appropriation of net primary production in Earth's terrestrial ecosystems. Proc. Natl. Acad. Sci. USA 2007, 104, 12942-12947.

6. Food and Agriculture Organization (FAO). Global Forest Resources Assessment 2010: Main Report; Food and Agriculture Organization of the United Nations: Rome, Italy, 2010; p. 376.

7. Corona, P.; Barbati, A.; Tomao, A.; Bertani, R.; Valentini, R.; Marchetti, M.; Fattorini, L.; Perugini, L. Land use inventory as framework for environmental accounting: An application in Italy. iForest-Biogeosci. For. 2012, 5, 204-209.

8. Deal, R.L.; Cochran, B.; LaRocco, G. Bundling of ecosystem services to increase forestland value and enhance sustainable forest management. For. Policy Econo. 2012, 17, 69-76.

9. Onaindia, M.; Fernández de Manuel, B.; Madariaga, I.; Rodríguez-Loinaz, G. Co-benefits and trade-offs between biodiversity, carbon storage and water flow regulation. For. Ecol. Manag. 2013, 289, 1-9.

10. Gren, I.-M.; Isacs, L. Ecosystem services and regional development: An application to Sweden. Ecol. Econ. 2009, 68, 2549-2559.

11. Ojea, E.; Ruiz-Benito, P.; Markandya, A.; Zavala, M.A. Wood provisioning in Mediterranean forests: A bottom-up spatial valuation approach. For. Policy Econ. 2012, 20, 78-88.

12. Hanson, D.A.; Britney, E.M.; Earle, C.J.; Stewart, T.G. Adapting Habitat Equivalency Analysis (HEA) to assess environmental loss and compensatory restoration following severe forest fires. For. Ecol. Manag. 2013, 294, 166-177.

13. Willaarts, B.A.; Volk, M.; Aguilera, P.A. Assessing the ecosystem services supplied by freshwater flows in mediterranean agroecosystems. Agric. Water Manag. 2012, 105, 21-31. 
14. Martínez, M.L.; Pérez-Maqueo, O.; Vázquez, G.; Castillo-Campos, G.; García-Franco, J.; Mehltreter, K.; Equihua, M.; Landgrave, R. Effects of land use change on biodiversity and ecosystem services in tropical montane cloud forests of Mexico. For. Ecol. Manag. 2009, 258, 1856-1863.

15. Leh, M.D.K.; Matlock, M.D.; Cummings, E.C.; Nalley, L.L. Quantifying and mapping multiple ecosystem services change in west Africa. Agric. Ecosyst. Environ. 2013, 165, 6-18.

16. Fabbio, G.; Merlo, M.; Tosi, V. Silvicultural management in maintaining biodiversity and resistance of forests in Europe-The Mediterranean region. J. Environ. Manag. 2003, 67, 67-76.

17. Busch, M.; la Notte, A.; Laporte, V.; Erhard, M. Potentials of quantitative and qualitative approaches to assessing ecosystem services. Ecol. Indic. 2012, 21, 89-103.

18. Paletto, A.; Chincarini, M. Heterogeneity of linear forest formations: Differing potential for biodiversity conservation. A case study in Italy. Agrofor. Syst. 2012, 86, 83-93.

19. Santopuoli, G.; Requardt, A.; Marchetti, M. Application of indicators network analysis to support local forest management plan development: A case study in Molise, Italy. iForest-Biogeosci. For. 2012, 5, 31-37.

20. Palliggiano, D.; Pedroni, P.; Pavanel, E.; Marconi, M.; Baizhigitova, A.; Sali, J.; Reed, T.; Howard, P. Addressing and managing reliance and potential impacts on biodiversity and ecosystem services of oil \& gas global operations. In Proceedings of the International Conference on Health, Safety and Environment in Oil and Gas Exploration and Production, Perth, Australia, 11-13 September, 2012.

21. Notaro, S.; Paletto, A. Links between mountain communities and environmental services in the Italian Alps. Sociol. Rural. 2011, 51, 137-157.

22. Horton, B.; Colarullo, G.; Bateman, I.J.; Peres, C.A. Evaluating non-user willingness to pay for a large-scale conservation programme in Amazonia: A UK/Italian contingent valuation study. Environ. Conserv. 2003, 30, 139-146.

23. Gatto, P.; Pettenella, D.; Secco, L. Payments for forest environmental services: Organisational models and related experiences in Italy. iForest-Biogeosci. For. 2009, 2, 133-139.

24. Pettenella, D.; Vidale, E.; Gatto, P.; Secco, L. Paying for water-related forest services: A survey on Italian payment mechanisms. iForest-Biogeosci. For. 2012, 5, 210-215.

25. Aretano, R.; Petrosillo, I.; Zaccarelli, N.; Semeraro, T.; Zurlini, G. People perception of landscape change effects on ecosystem services in small Mediterranean islands: A combination of subjective and objective assessments. Landsc. Urban Plan. 2013, 112, 63-73.

26. Mace, G.M.; Norris, K.; Fitter, A.H. Biodiversity and ecosystem services: A multilayered relationship. Trends Ecol. Evol. 2012, 27, 19-26.

27. Hooper, D.U.; Adair, E.C.; Cardinale, B.J.; Byrnes, J.E.K.; Hungate, B.A.; Matulich, K.L.; Gonzalez, A.; Duffy, J.E.; Gamfeldt, L.; O/'Connor, M.I. A global synthesis reveals biodiversity loss as a major driver of ecosystem change. Nature 2012, 486, 105-108.

28. Díaz, S.; Fargione, J.; Chapin, F.S., III; Tilman, D. Biodiversity loss threatens human well-being. PLoS Biol. 2006, 4, e277.

29. Cardinale, B.J.; Duffy, J.E.; Gonzalez, A.; Hooper, D.U.; Perrings, C.; Venail, P.; Narwani, A.; Mace, G.M.; Tilman, D.; Wardle, D.A.; et al. Biodiversity loss and its impact on humanity. Nature 2012, 486, 59-67. 
30. Keith, D.A.; Rodríguez, J.P.; Rodríguez-Clark, K.M.; Nicholson, E.; Aapala, K.; Alonso, A.; Asmussen, M.; Bachman, S.; Basset, A.; Barrow, E.G.; et al. Scientific foundations for an IUCN Red List of ecosystems. PLoS ONE 2013, 8, e62111.

31. European Commission. Our life insurance, our natural capital: An eu biodiversity strategy to 2020. In COM(2011) 244 Final; Commission, E., Ed.; European Commission: Brussels, Belgium, 2011.

32. Andreella, M.; Biliotti, M.; Bonella, G.; Cinquepalmi, F.; Duprè, E.; la Posta, A.; Luchetti, D.; Pettiti, L.; Tartaglini, N.; Vindigni, V. Strategia Nazionale per la Conservazione Della Biodiversità [Italian National Biodiversity Strategy]; Ministero dell'Ambiente e della Tutela del Territorio e del Mare: Rome, Italy, 2010; p. 120.

33. Schneiders, A.; van Daele, T.; van Landuyt, W.; van Reeth, W. Biodiversity and ecosystem services: Complementary approaches for ecosystem management? Ecol. Indic. 2012, 21, 123-133.

34. Bruner, A.G.; Gullison, R.E.; Rice, R.E.; da Fonseca, G.A.B. Effectiveness of parks in protecting tropical biodiversity. Science 2001, 291, 125-128.

35. Hockings, M. Systems for assessing the effectiveness of management in protected areas. BioScience 2003, 53, 823-832.

36. Chape, S.; Harrison, J.; Spalding, M.; Lysenko, I. Measuring the extent and effectiveness of protected areas as an indicator for meeting global biodiversity targets. Philos. Trans. R. Soc. B: Biol. Sci. 2005, 360, 443-455.

37. Scarascia-Mugnozza, G.; Oswald, H.; Piussi, P.; Radoglou, K. Forests of the Mediterranean region: gaps in knowledge and research needs. For. Ecol. Manag. 2000, 132, 97-109.

38. Agnoletti, M. Italian Historical Rural Landscapes: Cultural Values for the Environment and Rural Development; Springer: Dordrecht, the Netherlands, 2013.

39. Chemini, C.; Rizzoli, A. Land use change and biodiversity conservation in the Alps. J. Mt. Ecol. 2003, 7, 1-7.

40. Chiavetta, U.; Sallustio, L.; Garfi, V.; Maesano, M.; Marchetti, M. Classification of the oldgrowthness of forest inventory plots with dissimilarity metrics in Italian National Parks. Eur. J. For. Res. 2012, 131, 1473-1483.

41. Bennett, E.M.; Balvanera, P. The future of production systems in a globalized world. Front. Ecol. Environ. 2007, 5, 191-198.

42. Holling, C.S. Adaptive Environmental Assessment and Management; John Wiley \& Sons: Chichester, UK, 1978; p. 377.

43. Walters, C.J. Adaptive Management of Renewable Resources; Blackburn Press: Caldwell, NJ, USA 1986; p. 374.

44. Convention on Biological Diversity (CBD). The Ecosystem Approach: CBD Guidelines; Secretariat of the Convention on Biological Diversity: Montreal, QC, Canada, 2004; p. 50.

45. Gunderson, L.H. Ecological resilience-In theory and application. Ann. Rev. Ecol. Syst. 2000, 31, 425-439.

46. Walker, B.; Salt, D. Resilience Thinking: Sustaining Ecosystems and People in a Changing World; Island Press: Washington, DC, USA, 2006; p. 192.

47. Rist, L.; Moen, J. Sustainability in forest management and a new role for resilience thinking. For. Ecol. Manag. 2013, 310, 416-427.

48. Marchetti, M. International perspectives on the evolution of systemic silviculture. Ital. J. For. Mt. Environ. 2011, 66, 203-217. 
49. Daily, G.C.; Matson, P.A. Ecosystem services: From theory to implementation. Proc. Natl. Acad. Sci. USA 2008, 105, 9455-9456.

50. Nieto-Romero, M.; Oteros-Rozas, E.; González, J.A.; Martín-López, B. Exploring the knowledge landscape of ecosystem services assessments in Mediterranean agroecosystems: Insights for future research. Environ. Sci. Policy 2014, 37, 121-133.

51. Chiesura, A.; de Groot, R. Critical natural capital: A socio-cultural perspective. Ecol. Economics 2003, 44, 219-231.

52. Martín-López, B.; Iniesta-Arandia, I.; García-Llorente, M.; Palomo, I.; Casado-Arzuaga, I.; Amo, D.G.D.; Gómez-Baggethun, E.; Oteros-Rozas, E.; Palacios-Agundez, I.; Willaarts, B.; et al. Uncovering ecosystem service bundles through social preferences. PLoS ONE 2012, 7, e38970.

53. Milcu, A.I.; Hanspach, J.; Abson, D.; Fischer, J. Cultural ecosystem services: A literature review and prospects for future research. Ecol. Soc. 2013, 18, 44.

54. Cowling, R.M.; Egoh, B.; Knight, A.T.; O’Farrell, P.J.; Reyers, B.; Rouget, M.; Roux, D.J.; Welz, A.; Wilhelm-Rechman, A. An operational model for mainstreaming ecosystem services for implementation. Proc. Natl. Acad. Sci. USA 2008, 105, 9483-9488.

55. Thompson, I.; Mackey, B.; McNulty, S.; Mosseler, A. Forest Resilience, Biodiversity, and Climate Change. A Synthesis of the Biodiversity/Resilience/Stability Relationship in Forest Ecosystems; Secretariat of the Convention on Biological Diversity: Montreal, QC, Canada, 2009; p. 67.

56. Balvanera, P.; Pfisterer, A.B.; Buchmann, N.; He, J.-S.; Nakashizuka, T.; Raffaelli, D.; Schmid, B. Quantifying the evidence for biodiversity effects on ecosystem functioning and services. Ecol. Lett. 2006, 9, 1146-1156.

57. Gamfeldt, L.; Snall, T.; Bagchi, R.; Jonsson, M.; Gustafsson, L.; Kjellander, P.; Ruiz-Jaen, M.C.; Froberg, M.; Stendahl, J.; Philipson, C.D.; et al. Higher levels of multiple ecosystem services are found in forests with more tree species. Nat. Commun. 2013, 4, 1340.

58. McRoberts, R.E.; Winter, S.; Chirici, G.; LaPoint, E. Assessing forest naturalness. For. Sci. 2012, 58, 294-309.

59. Harrison, P. Ecosystem services and biodiversity conservation: An introduction to the RUBICODE project. Biodivers. Conserv. 2010, 19, 2767-2772.

60. Anton, C.; Young, J.; Harrison, P.; Musche, M.; Bela, G.; Feld, C.; Harrington, R.; Haslett, J.; Pataki, G.; Rounsevell, M.A.; et al. Research needs for incorporating the ecosystem service approach into EU biodiversity conservation policy. Biodivers. Conserv. 2010, 19, 2979-2994.

61. Maes, J.; Teller, A.; Erhard, M.; Liquete, C.; Braat, L.; Berry, P.; Egoh, B.; Puydarrieux, P.; Fiorina, C.; Santos, F.; et al. Mapping and Assessment of Ecosystems and Their Services. An Analytical Framework for Ecosystem Assessments under Action 5 of the EU Biodiversity Strategy to 2020; Publications office of the European Union: Luxembourg, 2013; p. 57.

62. Chirici, G.; Sallustio, L.; Vizzarri, M.; Marchetti, M.; Barbati, A.; Corona, P.; Travaglini, D.; Cullotta, S.; Lafortezza, R.; Lombardi, F. Advanced earth observation approach for multiscale forest ecosystem services modeling and mapping (MIMOSE). Annali di Botanica 2014, 4, $27-34$.

63. Kumar, P. The Economics of Ecosystems and Biodiversity: Ecological and Economic Foundations; Earthscan: London, UK, 2010; p. 410.

64. Brouwer, R.; Brander, L.; Kuik, O.; Papyrakis, E.; Bateman, I. A Synthesis of Approaches to Assess and Value Ecosystem Services in the EU in the Context of TEEB: Final Report; University of Amsterdam: Amsterdam, The Netherlands, 2013; p. 144. 
65. ISTAT. Ricerca e sviluppo in Italia. Anno 2011. (Research and development in Italy: Year 2011); ISTAT (Istituto Italiano di Statistica): Rome, Italy, 2011; p 10.

66. Duprè, E.; Maggiore, A.M.; Martino, D.; Patriarca, D.; Petrucci, B.; Scanu, G.; Tartaglini, N. Parchi Nazionali: Dal Capitale Naturale alla Contabilità Ambientale (National Parks in Italy: From Natural Capital to Environmental Accounting); Ministero dell'Ambiente e della Tutela del Territorio e del Mare: Rome, Italy, 2013; p. 57.

67. Mulongoy, K.J.; Chape, S. Protected areas and biodiversity: An overview of key issues. Unep-wcmc biodiversity series 21; CBD, UNEP-WCMC: Cambridge, UK; Montreal, Canada, 2004; Volume 2004.

68. Naughton-Treves, L.; Holland, M.B.; Brandon, K. The role of protected areas in conserving biodiversity and sustaining local livelihoods. Ann. Rev. Environ. Resour. 2005, 30, 219-252.

69. Motta, R.; Haudemand, J.-C. Protective forests and silvicultural stability. Mt. Res. Dev. 2000, 20, 180-187.

70. Croitoru, L. Valuing the non-timber forest products in the Mediterranean region. Ecol. Econ. 2007, 63, 768-775.

71. Raudsepp-Hearne, C.; Peterson, G.D.; Bennett, E.M. Ecosystem service bundles for analyzing tradeoffs in diverse landscapes. Proc. Natl. Acad. Sci. USA 2010, 107, 5242-5247.

72. Vermeulen, S.; Koziell, I. Integrating Global and Local Values: A Review of Biodiversity Assessment; International Institute for Environment and Development: London, UK, 2002; p. 104.

73. Hein, L.; van Koppen, K.; de Groot, R.S.; van Ierland, E.C. Spatial scales, stakeholders and the valuation of ecosystem services. Ecol. Econ. 2006, 57, 209-228.

74. Folke, C.; Hahn, T.; Olsson, P.; Norberg, J. Adaptive governance of social-ecological systems. Ann. Rev. Environ. Resour. 2005, 30, 441-473.

75. Marino, D.; Marucci, A.; Palmieri, M.; Gaglioppa, P. Monitoring the Convention on Biological Diversity (CBD) framework using evaluation of effectiveness methods. The Italian case. Ecol. Indic. 2015, 55, 172-182.

76. Nolte, C.; Leverington, F.; Kettner, A.; Marr, M.; Nielsen, G.; Bomhard, B.; Stolton, S.; Stoll-Kleemann, S.; Hockings, M. Protected Area Management Effectiveness Assessments in Europe: A Review of Application, Methods and Results; BfN-Skripten: Bonn, Germany, 2010; p. 69.

77. Borrini-Feyerabend, G.; Dudley, N.; Jaeger, T.; Lassen, B.; Pathak Broome, N.; Phillips, A.; Sandwith, T. Governance of Protected Areas: From Understanding to Action; IUCN: Gland, Switzerland, 2013; p. 124.

78. Ciancio, O.; Corona, P.; Marchetti, M.; Nocentini, S. Linee Guida per la Gestione Sostenibile Delle Risorse Forestali e Pastorali nei Parchi Nazionali [Sustainable Forest Management Guide-Lines in National Parks in Italy]; Ministero dell'Ambiente e della Tutela del Territorio - Accademia Italiana di Scienze Forestali: Firenze, Italy, 2002.

79. Daily, G.C.; Ouyang, Z.; Zheng, H.; Li, S.; Wang, Y.; Feldman, M.; Kareiva, P.; Polasky, S.; Ruckelshaus, M. Securing natural capital and human well-being: Innovation and impact in china. Acta Ecol. Sin. 2013, 33, 677-685. 
80. UK National Ecosystem Assessment (UK-NEA). The UK National Ecosystem Assessment: Synthesis of the Key Findings; UNEP-WCMC: Cambridge, UK, 2011; p. 87.

(C) 2015 by the authors; licensee MDPI, Basel, Switzerland. This article is an open access article distributed under the terms and conditions of the Creative Commons Attribution license (http://creativecommons.org/licenses/by/4.0/). 